\title{
2008 GEOTHERMAL TECHNOLOGIES MARKET REPORT
}

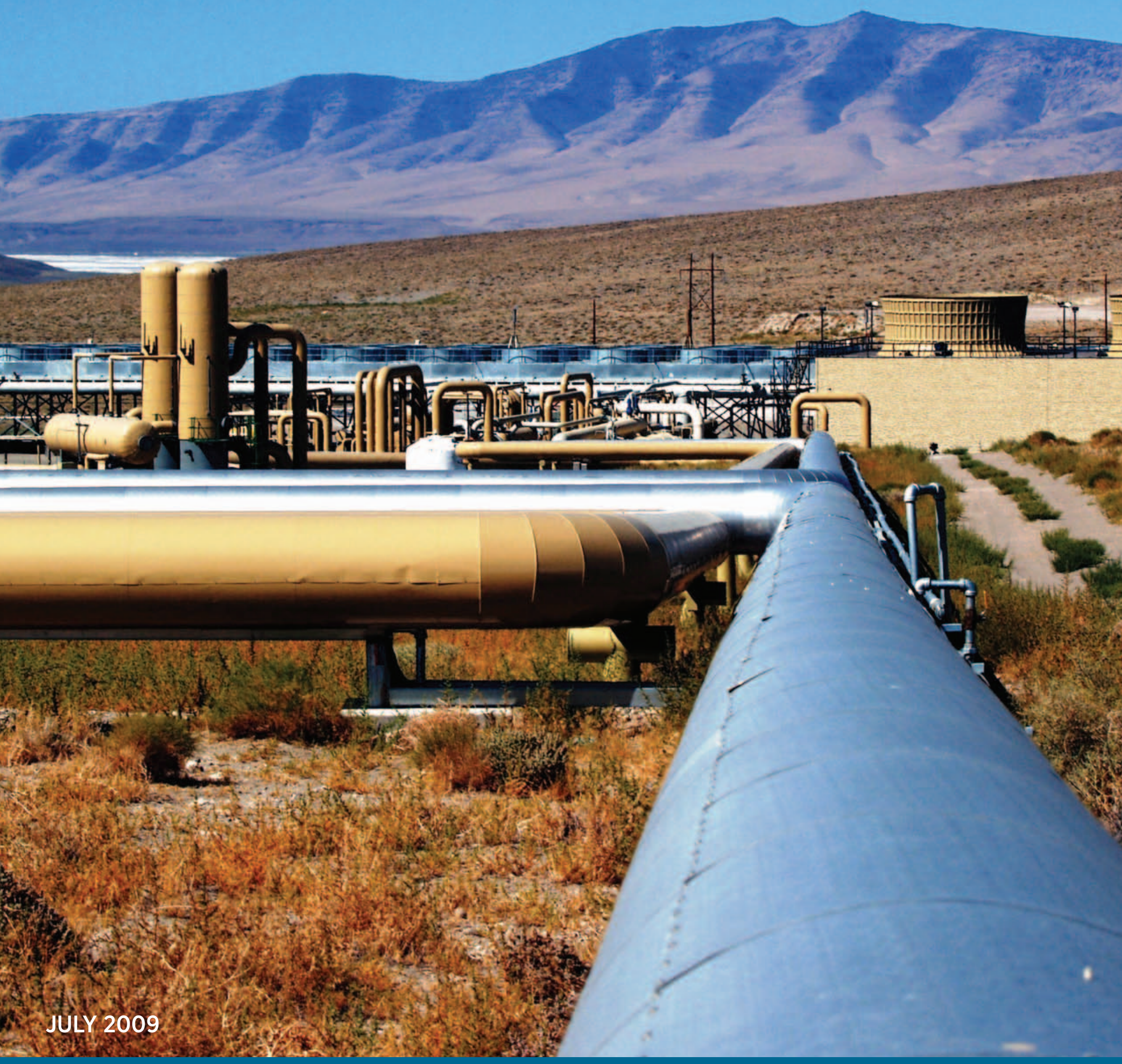


(This page intentionally left blank) 


\section{Table of Contents}

Executive Summary

Major 2008 Highlights

1

2

1. Introduction ................................................................. 4

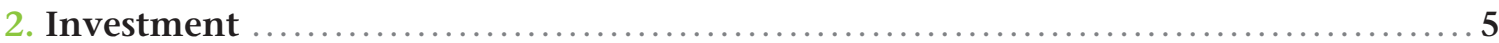

The 2008 Geothermal Technologies Program: $\$ 44$ M for EGS RD\&D . . . . . . . . . . . . . . . . . . . . 5

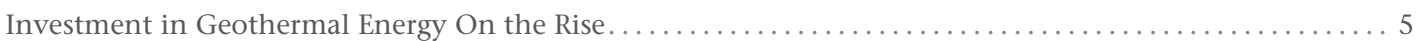

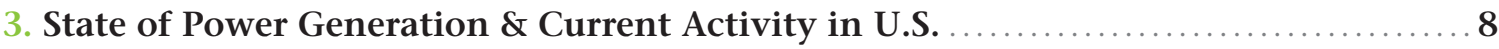

Geothermal Industry Participants Increase Substantially in $2008 \ldots \ldots \ldots \ldots \ldots \ldots \ldots \ldots \ldots \ldots \ldots \ldots$

GTP 2008 Funding Opportunity Announcement Receives

the Largest Number of Applicants in the Program's History . . . . . . . . . . . . . . . . . . . . . 9

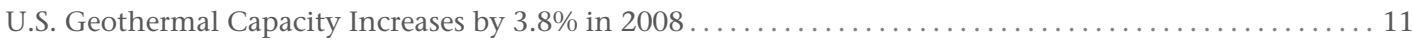

USGS Releases the First National Geothermal Assessment in More Than 30 Years (September 2008) ..... 13

The Geothermal Development Pipeline in 2008: 126 Projects with 3,638-5,650 MWe of Capacity ..... 14

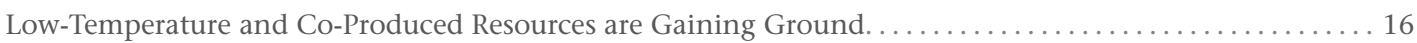

New Binary Plant Designs Reduce Construction Lead Time $\ldots \ldots \ldots \ldots \ldots \ldots \ldots \ldots \ldots \ldots \ldots \ldots \ldots \ldots \ldots \ldots \ldots \ldots \ldots \ldots$

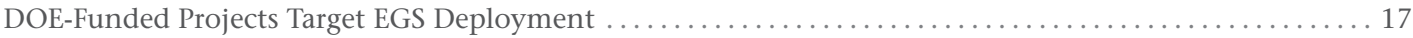

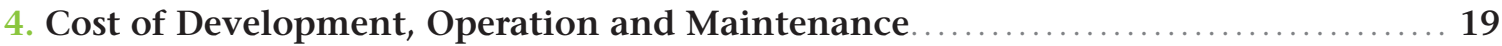

Conventional Hydrothermal Plants Typically Cost $\$ 3,000$ to $\$ 4,000$ per Installed KW ............. 19

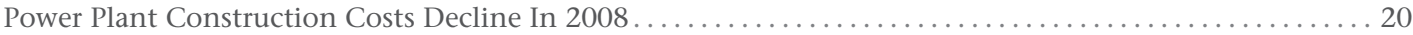

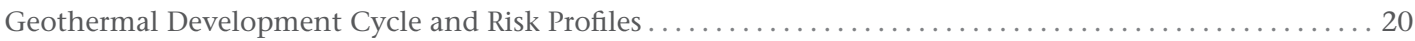

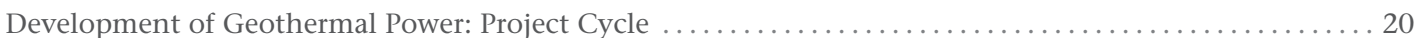

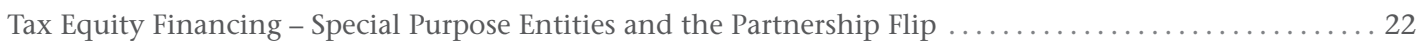

Availability of Geothermal Project Financing Declines in $2008 \ldots \ldots \ldots \ldots \ldots \ldots \ldots \ldots \ldots \ldots \ldots \ldots \ldots \ldots \ldots \ldots \ldots \ldots \ldots \ldots$

Geothermal Costs Less than Other Renewables and Some Conventional Sources .................... 24 
5. National Policy, Geothermal Leasing and Permitting ......................... 26

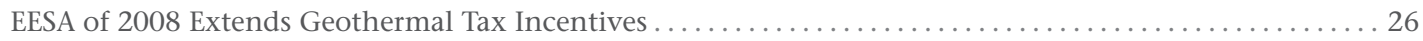

Renewable Portfolio Standards are Drivers for Renewable Energy Development ................ 26

Western Renewable Energy Zone to Expedite Renewable Energy Development and Delivery ........... 27

EPAct 2005: New Procedures for Federal Geothermal Leases ................................ 27

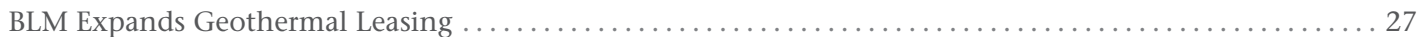

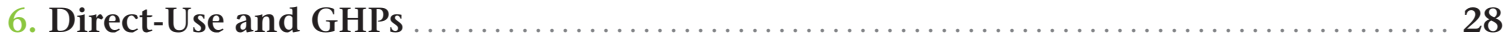

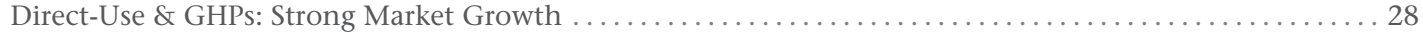

The U.S. GHP Installed Base is World's Largest: More than 1 Million Units . . . . . . . . . . . . . . . . . 29

U.S. GHP Market Segmentation - Evenly Divided Between Residential and Commercial Applications ... 30

Four Companies Hold 80 Percent of U.S. GHP Market $\ldots \ldots \ldots \ldots \ldots \ldots \ldots \ldots \ldots \ldots \ldots \ldots \ldots \ldots \ldots \ldots \ldots \ldots \ldots \ldots \ldots \ldots \ldots$

Tax Credits and Incentives Set to Increase GHP Deployment $\ldots \ldots \ldots \ldots \ldots \ldots \ldots \ldots \ldots \ldots \ldots \ldots \ldots \ldots \ldots \ldots \ldots$

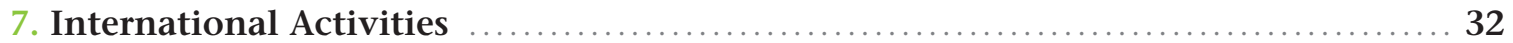

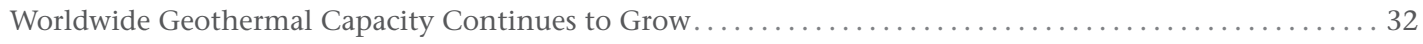

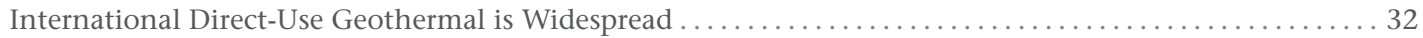

8. Employment and Economic Benefits of Geothermal Power.................... 34

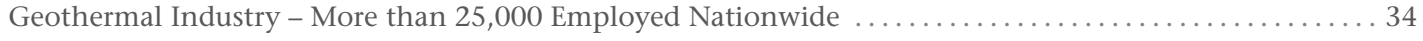

Gross Revenue from Geothermal Royalties Increased 14\% between FY 2006-2008 ................ 34

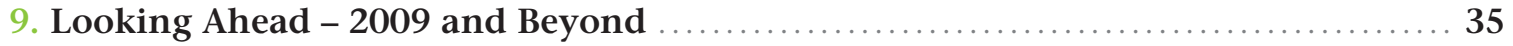

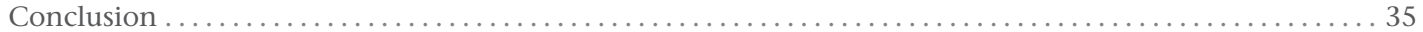

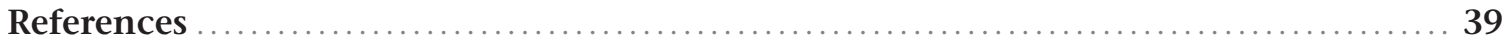

\section{Primary Authors:}

Jonathan Cross

New West Technologies, LLC

Jeremiah Freeman

New West Technologies, LLC

\section{Acknowledgements}

This report was made possible by the U.S. Department of Energy (DOE) Geothermal Technologies Program (GTP). The authors thank Jørn Aabakken, Alison Wise, Rachel Gelman (National Renewable Energy Laboratory) and Alexandra Pressman (Sentech) for technical input; and Lauren Boyd, Nicole Reed, Mike Murphy (DOE GTP) and Agatha Wein (New West Technologies) for comments on drafts throughout the process. The authors also thank Christina Van Vleck for graphic design. Of course, any remaining errors or omissions are the fault of the authors. 


\section{Executive Summary}

Geothermal energy has been exploited for power generation since at least $1904 .{ }^{1}$ However, the last few years have witnessed a conspicuous revival in interest in geothermal technologies both old and new. In fact, 2008 was a watershed year for the industry. The U.S. Department of Energy (DOE) revived its Geothermal Technologies Program (GTP) with new funding that made possible substantial new investments in geothermal research, development and technology demonstration. The U.S. Department of the Interior's (DOI) Bureau of Land Management (BLM) also significantly increased the amount of Federal land available for geothermal exploration and development and worked to streamline the complex permitting and leasing process. Installed geothermal capacities in the United States and abroad continued to increase as well.

Despite the positive advances for geothermal in recent years, strains from the global economic downturn that started late in 2008 are beginning to have an effect on financing in the industry. Geothermal power developers rely heavily on the equity markets and financing based on the monetization of production tax credits (PTCs), and these sources of capital are no longer readily accessible. Geothermal development also has a steep, front-loaded risk profile that makes projects very difficult to finance; exploratory drilling is an extremely expensive step early in the development process that carries the greatest risk.

Geothermal markets are also being affected by the downturn of the Icelandic economy. A particularly poignant example is the nationalization of Glitnir Bank, now Íslandsbanki, which was adept at providing geothermal developers with funding necessary to support risky exploration and drilling activities until they were able to secure financing from traditional sources. When it was nationalized by the Icelandic government in September of 2008, Glitnir largely disappeared from the pool of potential geothermal financing sources. Unfortunately, they were not the only financier of geothermal development to fall victim to the economic downturn. Only half of the 14 large financial companies that funded renewable energy projects over the past few years are still active today. ${ }^{2}$

In contrast to the economic arena, the policy environment in 2008 was favorable to continued geothermal power development. In the United States, the Emergency Economic Stabilization Act (EESA) of 2008, signed by President Bush on October 3, 2008, extended PTCs for geothermal energy production until January 1, 2011. The legislation also reinstituted a 30\% individual tax credit for qualifying geothermal heat pumps (GHPs), capped at $\$ 2,000 .^{3}$ Additionally, state renewable portfolio standards (RPS) remained an effective driver for investments in a variety of renewable energy technologies, including geothermal.

At the non-electricity generating end of the geothermal technology spectrum, the market for GHPs continued to experience rapid growth despite the downturn in financial and real estate sectors. 
The Air-Conditioning, Heating and Refrigeration Institute (AHRI) reported 2008 shipments of more than 71,000 units, indicating continued strong demand. The heat pump market still faces significant barriers, however, including: high installation and capital costs; a pervasive lack of consumer awareness; and insufficient market delivery infrastructure. In order for heat pumps to reach their full market potential, these barriers must be addressed through effective market conditioning strategies.

Low-temperature geothermal direct use applications typically include spas, district space heating, aquaculture, agricultural drying, and snow melting. ${ }^{*}$ Though these applications remain only a small portion of total geothermal resource use in the United States, it is still noteworthy that their installed base has doubled in the past 15 years. ${ }^{4}$ Direct-use geothermal energy is widely used internationally, including in Iceland, China and Japan. In Japan, geothermal power developers are competing with spa, hotel, and bath projects to access the direct-use energy resources.

Geothermal co-production with oil and gas is another exciting and likely possibility for the near future. These developments, along with the enormous potential of enhanced geothermal systems (EGS) projects, will transform geothermal energy in the United States from a western state-focused energy source into a ubiquitous source of baseload power.

In conclusion, this is a particularly exciting time for the geothermal energy industry. Even in the face of a troubled economic climate, it seems likely that the next few years will see a marked increase in the use geothermal energy to meet the nation's growing electricity demand requirements.

\section{Major 2008 Highlights}

- 110 additional MW of geothermal power came online in the United States. (100 MW from binary plants and $10 \mathrm{MW}$ from steam plants).

- The GTP made 21 awards totaling \$43.1 million over four years. ${ }^{5}$

- Google.org, Google's philanthrophic arm, gave over \$10 million in grants to two gethermal companies and one research university to support their work on EGS. Google's name-brand support thrust geothermal into the public spotlight and improved its standing as a viable alternative energy source, alongside wind and solar. ${ }^{6}$

- BLM leased 301,588 acres of land for geothermal power development, a substantial addition to the 244,000 acres leased for this purpose since July of 2007.7

- The United States signed the International Partnership for Geothermal Technology (IPGT) with Iceland and Australia. The IPGT will lead to joint technology development projects with partner countries, reducing the cost of advanced geothermal technology development for each country and increasing the available expertise for specific projects. ${ }^{\dagger}$

- The economy-wide credit crunch dried up equity markets, making it extremely difficult for geothermal developers to locate financing for their projects.

- Glitnir Bank collapsed, taking with it an important source of geothermal financing.

- Price drops in the market for PTCs decreased their efficacy.

* Some authorities include GHPs in the direct-use category but they are treated separately in this paper.

† The International Partnership for Geothermal Technology (www.internationalgeothermal.org) 
- Investments in geothermal continued to increase.

- Small, low-temperature power generation units began to account for a significant portion of the overall geothermal market, a trend expected to continue for at least the next several years.

- Modular low-temperature electricity generation units gained popularity. These units have the potential to become a major contributor to the national geothermal energy portfolio over the next few years. 


\section{Introduction}

While geothermal energy technology has been in development in the United States for over 100 years ${ }^{*}$, national interest in geothermal recently gained momentum as the result of new analysis that suggests massive electricity producing potential. The geothermal industry has also seen unprecedented investment growth following the transition to a new administration and its response to the economic climate through the American Recovery and Reinvestment Act of 2009 (the Recovery Act). While it tends to have a lower profile among the nation's renewable energy resources, geothermal is currently in the midst of a renaissance. In such a rapidly changing market, this report bears particular significance.

Geothermal energy technologies can be broken into four major categories: conventional hydrothermal, low-temperature, EGS, and direct use, including geothermal heat pumps (GHPs). The first three categories generate electricity, while the fourth is used primarily for heating and cooling and hot water production. This report will consider electricity generation technologies separately from direct use technologies due to differences in technology maturity and market characteristics.

This report describes market-wide trends for the geothermal industry throughout 2008 and the beginning of 2009. It begins with an overview of the GTP's involvement with the geothermal industry and recent investment trends for electric generation technologies. The report next describes the current state of geothermal power generation and activity within the United States, costs associated with development, financing trends, an analysis of the levelized cost of energy (LCOE), and a look at the current policy environment. The report also highlights trends regarding direct use of geothermal energy, including GHPs. ${ }^{\dagger}$ The final sections of the report focus on international perspectives, employment and economic benefits from geothermal energy development, and potential incentives in pending national legislation.

\footnotetext{
* While geothermal energy has been in use for over 100 years within the United States, its use for electrical production dates back to 1922. The first large-scale geothermal power plant began operation in 1960. See http://www1.eere.energy.gov/geothermal/history.html.

† GHPs are also commonly referred to as ground source heat pumps.
} 


\section{Investment}

\section{The 2008 Geothermal Technologies Program: \$44M for EGS RD\&D}

Combined with rising energy prices and climate change concerns, significant renewed interest in geothermal energy came in 2007 with the release of Massachusetts Institute of Technology (MIT) report, "The Future of Geothermal Energy: Impact of Enhanced Geothermal Systems (EGS) on the United States in the $21^{\text {st }}$ Century." This report presented exciting new research that has already had a profound effect on overall energy investment in the United States, suggesting that given appropriate funding, 100,000 MWe of geothermal could be developed through EGS technologies within 50 years. After the release of the MIT report, Congress directed the GTP to refocus its program onto the development and eventual deployment of EGS technology due to its potential as a nationwide energy resource. The GTP received an infusion of funding during the 2008 Fiscal Year of approximately $\$ 20$ million (see Table 1).

Table 1. GTP Budget Request FY 2007-2009

\begin{tabular}{|c|c|c|c|c|c|}
\hline & \multicolumn{5}{|c|}{ Funding (\$ in thousands) } \\
\hline & $\begin{array}{l}\text { FY } 2007 \\
\text { Approp. }\end{array}$ & $\begin{array}{l}\text { FY } 2008 \\
\text { Request }\end{array}$ & $\begin{array}{l}\text { FY } 2008 \\
\text { Approp. }\end{array}$ & $\begin{array}{l}\text { FY } 2009 \\
\text { Request }\end{array}$ & $\begin{array}{l}\text { FY } 2009 \\
\text { Approp. }\end{array}$ \\
\hline $\begin{array}{r}\text { Enhanced } \\
\text { Geothermal Systems }\end{array}$ & 2,000 & 0 & 19,818 & 30,000 & 44,000 \\
\hline $\begin{array}{r}\text { Oil and Gas Well } \\
\text { Co-Production and } \\
\text { Resource Assessment }\end{array}$ & 3,000 & 0 & 0 & 0 & 0 \\
\hline TOTAL & 5,000 & 0 & 19,818 & 30,000 & 44,000 \\
\hline
\end{tabular}

Source: DOE, "EERE Fiscal-Year 2009: Budget-in-Brief"

\section{Investments in Geothermal Energy On the Rise}

Though 2008 presented enormous economic challenges, private investments in geothermal energy actually increased over prior years. Public market investment, project acquisitions, and venture capital (VC)/private equity (PE) have shown a marked increase from 2005-2008 (Figure 1), with U.S. projects receiving the majority of worldwide investment in geothermal development in 2007 (Figure 2). 
In 2007 and 2008, as the number of geothermal industry players grew, so did total investments in the sector. Many of these new developers are relatively small companies with few assets that are particularly vulnerable as the result of shrinking equity markets. Adding to the challenge, geothermal projects are notoriously difficult to finance because of large up-front capital costs, high risk, and long lead-time (see Financing section for more detail). ${ }^{8}$

Íslandsbanki, formerly known as Glitnir, has played an integral part in geothermal project financing, particularly during the early, high-risk stages of development. The nationalization of the Icelandic bank in 2008 ended its involvement in the U.S. geothermal industry. This blow to the industry did not result in a major setback because the crash of credit markets in this time period resulted in a lack of funding across all sectors. ${ }^{9}$

Figure 1. Trends in U.S. Geothermal Investments (2005-2008)

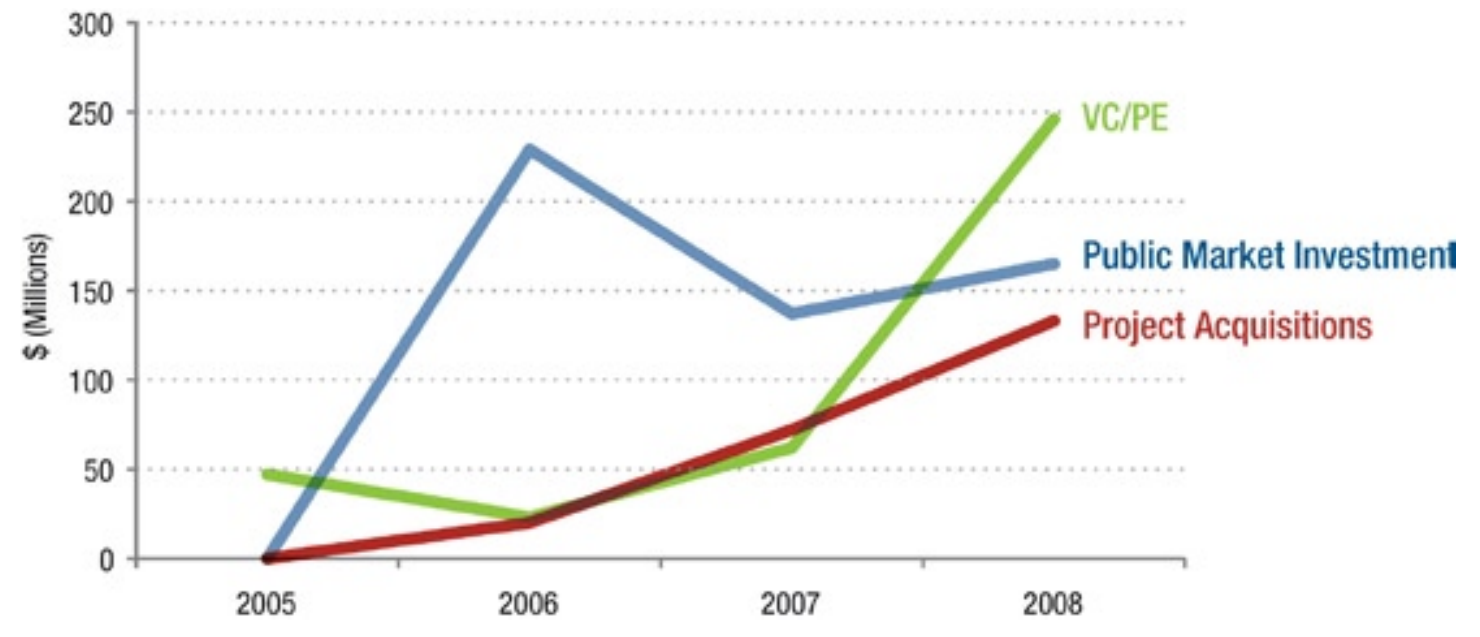

Source: New Energy Finance, January, 2009

Figure 2. U.S. and International Geothermal Investments

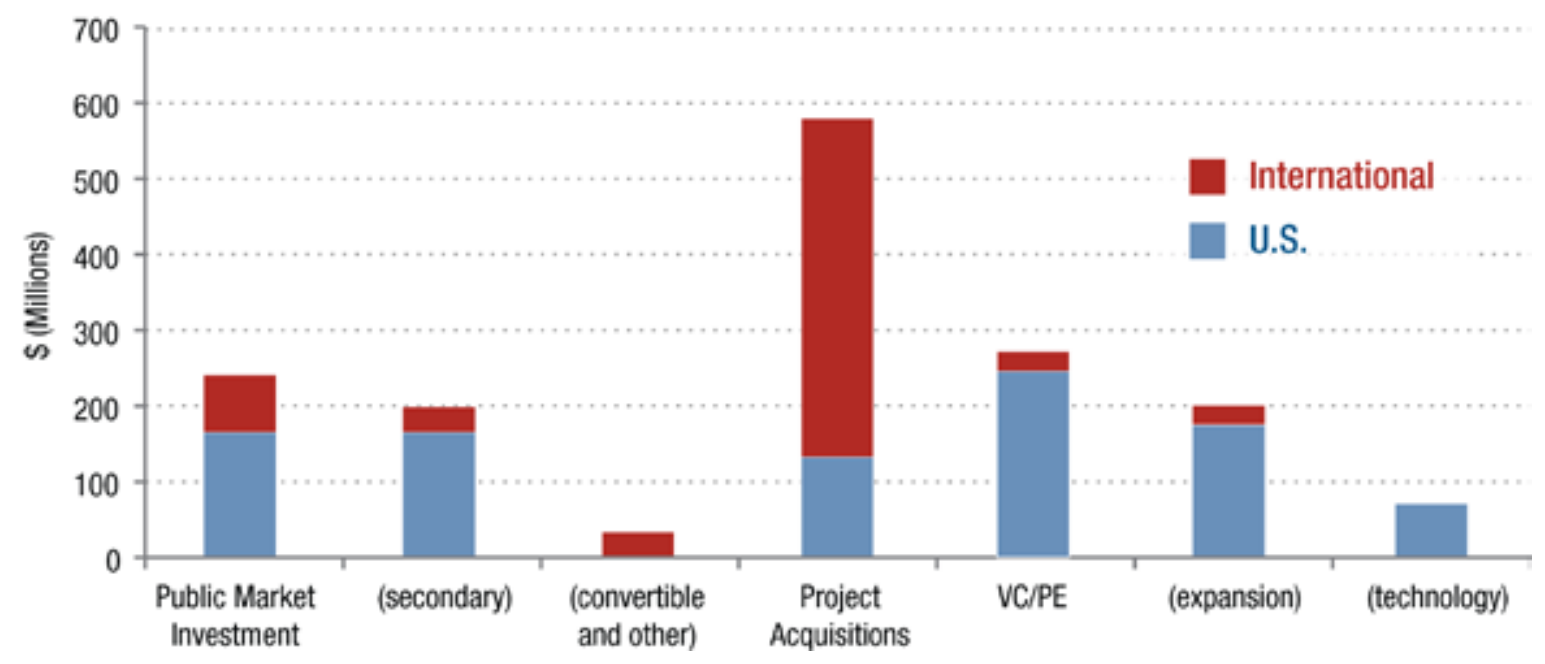

Source: New Energy Finance, January, 2009 
The highest-profile geothermal investment of 2008 came from Google. The tech giant's philanthropic arm, Google.org, provided $\$ 10$ million in grants to two companies, AltaRock Energy and Potter Drilling, and a geothermal research institution at Southern Methodist University (SMU) (see Table 2). Specifically, AltaRock Energy was awarded \$6 million to support the advancement of EGS, and Potter Drilling received \$4 million to develop its breakthrough drilling technology, hydrothermal spallation; a prototype is expected sometime in 2009. Lastly, the Geothermal Laboratory at SMU received nearly $\$ 500,000$ to improve geothermal resource assessment techniques and update the Geothermal Map of North America. Although Google's investment was one of many made in geothermal research over the course of the year, it is especially significant for the publicity that it generated.

Table 2: Google.org Funding for Geothermal Research

\begin{tabular}{|l|r|}
\hline Awardees & \multicolumn{1}{|c|}{ Funding } \\
\hline AltaRock Energy & $\$ 6,000,000$ \\
\hline Potter Drilling & $\$ 4,000,000$ \\
\hline SMU Geothermal Lab & $\$ 489,521$ \\
\hline
\end{tabular}

Source: Google.org, 2008 


\section{State of Power Generation \& Current Activity in the U.S.}

Geothermal Industry Participants Increase Substantially in 2008

In October 2008, 79 companies participated in the tradeshow at the Geothermal Resource Council (GRC) and Geothermal Energy Association (GEA) annual meeting in Reno, Nevada, compared to 51 in $2007 .{ }^{10}$ While some vertically integrated firms perform all stages of development, others specialize in one or two specific stages such as drilling or engineering and construction. For an overview of all the commercial players in the geothermal industry, it is useful to classify them according to their stage of development.

Figure 3. Companies in the Geothermal Value Chain (not comprehensive) *

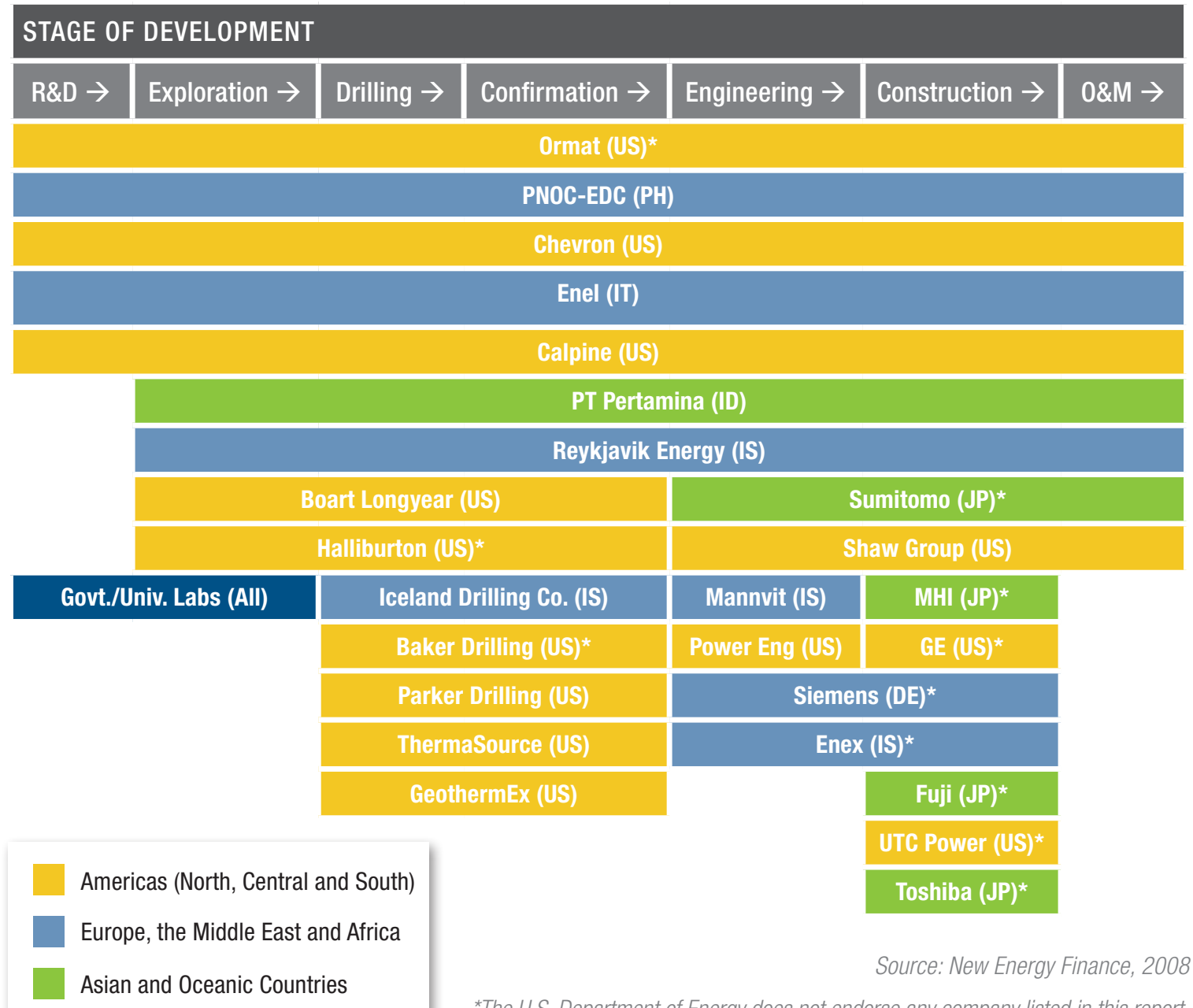


The information shown in Figure 3 comes from industry surveys by New Energy Finance and includes several of the most prominent commercial hydrothermal and EGS geothermal developers, but is not an exhaustive list. Five of these companies are vertically integrated, and represent the leaders of the industry: Ormat (U.S.), PNOC-EDC (Philippines), Chevron (U.S.), Enel (Italy), and Calpine (U.S.). Two firms perform all stages except research and development (R\&D): PT Pertamina (India) and Reykjavik Energy (Iceland). Six companies in the United States are dedicated to drilling and confirmation: Baker Drilling, Parker Drilling, ThermaSource, and Geothermex; along with Boart Longyear, and Halliburton who also perform exploration.

\section{GTP 2008 Funding Opportunity Announcement Receives the Largest Number of Applicants in the Program's History}

In October of 2008, DOE awarded $\$ 43.1$ to 21 applicants over four years for research, development and demonstration (RD\&D) associated with EGS. ${ }^{*}$ This is the greatest number of award recipients and of first-time recipients, 13 of the 21, in the history of the program (See Table 3). Specifically, for the 2008 fiscal year, \$8.7 million was awarded to fund 17 component technologies research and development projects, while roughly $\$ 11.1$ million was provided for the four demonstrative projects.

Table 3: GTP FOA Awardees: October 2008

\begin{tabular}{|c|c|c|c|}
\hline \multicolumn{4}{|l|}{ COMPONENT TECHNOLOGIES R\&D } \\
\hline Awardees & Location & Project Description & Funding \\
\hline - Baker-Hughes, Inc. & Houston, Texas & $\begin{array}{l}\text { Develop an ultrasonic } \\
\text { borehole televiewer }\end{array}$ & $\$ 3,139,364$ \\
\hline $\begin{array}{l}\text { - Colorado School of Mines } \\
\text { - Boise State University } \\
\text { - Flint, LLC } \\
\text { - Mt. Princeton Geothermal, LLC }\end{array}$ & Golden, Colorado & $\begin{array}{l}\text { Geophysical characterization } \\
\text { of geothermal systems using } \\
\text { joint inversion of electrical } \\
\text { and seismic data }\end{array}$ & $\$ 867,564$ \\
\hline $\begin{array}{l}\text { - Composite Technology } \\
\text { - Wood Group ESP } \\
\text { - New England Wire Technology }\end{array}$ & Lafayette, Colorado & $\begin{array}{l}\text { Develop high temperature } \\
\text { motor windings for electric } \\
\text { submersible pumps }\end{array}$ & $\$ 987,739$ \\
\hline $\begin{array}{l}\text { - Foulger Consulting } \\
\text { - Geosystem with WesternGeco } \\
\text { - US Navy } \\
\text { - Magma Energy US Corporation } \\
\text { - Lawrence Berkeley National Laboratory }\end{array}$ & Menlo Park, California & $\begin{array}{l}\text { Develop tools and methods } \\
\text { suited to monitoring EGS- } \\
\text { induced micro-earthquakes }\end{array}$ & $\$ 561,729$ \\
\hline $\begin{array}{l}\text { - GE Global Research } \\
\text { - Auburn University } \\
\text { - GE Energy }\end{array}$ & Niskayuna, New York & $\begin{array}{l}\text { Develop high temperature } \\
\text { electronics platform and } \\
\text { temperature sensor }\end{array}$ & $\$ 1,599,934$ \\
\hline $\begin{array}{l}\text { - Hattenbrug, Dilley, and Linnell, LLC } \\
\text { - University of Utah }\end{array}$ & Anchorage, Alaska & $\begin{array}{l}\text { Use of Fluid Inclusion } \\
\text { Stratigraphy (FIS) chemical } \\
\text { signature to identify open } \\
\text { fracture systems }\end{array}$ & $\$ 313,858$ \\
\hline
\end{tabular}

* DOE's commitment of $\$ 43.1$ million is subject to annual appropriations. 
- Hi-Q Geophysical Inc.

- Ormat Technologies Inc.

- Lawrence Berkeley National Laboratory

- MIT

- Chevron

- Los Alamos National Laboratory

- MIT

- New England Research

- Perma Works and Frequency Management International

- ElectroChemical Systems Inc

- Draka Cableteq

- Pacific Systems Inc

- Tiger Wireline Inc

- Viking Engineering

- Kuster Company

- Electronic Workmanship Standards, Inc.

- Eclipse NanoMed

- Honeywell SSEC

- Schlumberger

- Schlumberger

- Stanford University

- Texas A\&M University

- Sandia National Laboratory

- University of Mississippi

- Texas A\&M University

- Sandia National Laboratory

- University of Mississippi

- University of Utah

- University of Utah

\begin{tabular}{l|l|r}
\hline Ponca City, Oklahoma & $\begin{array}{l}\text { Develop surface and borehole } \\
\text { seismic methodologies }\end{array}$ & $\$ 817,757$ \\
\hline $\begin{array}{l}\text { Cambridge, } \\
\text { Massachusetts }\end{array}$ & $\begin{array}{l}\text { Develop geomechanical } \\
\text { model of reservoir fluid flow }\end{array}$ & $\$ 508,633$ \\
\hline $\begin{array}{l}\text { Cambridge, } \\
\text { Massachusetts }\end{array}$ & $\begin{array}{l}\text { Combine geophysical } \\
\text { methods with a rock } \\
\text { physics model for fracture } \\
\text { characterization }\end{array}$ & $\$ 1,019,769$ \\
\hline $\begin{array}{l}\text { Albuquerque, } \\
\text { New Mexico }\end{array}$ & $\begin{array}{l}\text { Develop high-temperature } \\
\text { well monitoring tools }\end{array}$ & $\$ 2,200,000$ \\
\hline
\end{tabular}

well monitoring tools
$\$ 1,245,751$

operating range of electric

submersible pumps

Sugar Land, Texas

Develop downhole

$\$ 1,253,959$

monitoring system for electric

submersible pumps

Stanford, California

Develop wellbore tools

$\$ 967,541$

and reservoir engineering

approaches

College Station, Texas

Develop improved

$\$ 820,198$

seismicity-based reservoir

characterization technology

techniques

College Station, Texas

Develop three-dimensional numerical model to predict

reservoir stimulation

Salt Lake City, Utah

Demonstrate absorbing

$\$ 1,091,039$

tracers and develop

fluorimeter to measure

tracer concentration

Salt Lake City, Utah Investigate fracture stability

$\$ 978,180$ 


\section{SYSTEMS DEMONSTRATION}

\section{Awardees}

Location

Project Description

Funding

- AltaRock Energy Inc

Seattle, Washington

Demonstrate innovative

- Northern California Power Agency

stimulation process to create

- University of Utah

- Texas A\&M University

- SAIC

- Temple University

- Geysers Power Co. LLC

- Lawrence Berkeley National Laboratory

- Ormat Nevada, Inc

- Lawrence Berkeley National Laboratory

- University of Utah

- Pinnacle Technologies

- GeoMechanics International

- University of Nevada - Reno

- TerraTex/Schlumberger

- University of Utah

- APEX Petroleum Engineering Services

EGS reservoir by drilling below permeable zone and stimulating low permeability zone

Middletown, California De

Demonstrate deepening

of wells into high-

temperature zones

\begin{tabular}{l|l} 
Reno, Nevada & Demonstrate ability to
\end{tabular}

stimulate multiple wells

at Brady Field, Nevada

- HiPoint Reservoir Imaging

- Chevron

hydraulic stimulation of

existing injection well at

Raft River Idaho

System Demonstrations Total

$\$ 24,015,480$

Total Department of Energy Funding

Source: DOE EE/RE

These RD\&D projects target GTP's goal of reaching EGS technology readiness by 2015 . Though successful EGS development will provide long-term nationwide benefits, near-term gains in geothermal expansion will likely come from conventional high-temperature hydrothermal, co-produced fluids, and low-temperature resources once considered uneconomical for commercial electricity generation.

\section{U.S. Geothermal Capacity Increases by $3.8 \%$ in 2008}

In 2008, an estimated 110 MWe of nameplate capacity was installed within the United States, bringing the cumulative total to 3,040 MWe (see Table 4). Of this total, $100 \mathrm{MWe}$ was sourced from binary plants and 10 from steam plants. 
Table 4. New Geothermal Power Plants Online in 2008

\begin{tabular}{|c|l|l|c|}
\hline Start Year & State & Power Plant & Nameplate Capacity (MWe) \\
\hline 2008 & Idaho & Raft River & 15.8 \\
\hline 2008 & Nevada & Galena & 20.0 \\
\hline 2008 & New Mexico & Lightning Dock & 0.24 \\
\hline 2008 & Utah & Hatch & 14.0 \\
\hline 2008 & Wyoming & NPR3 & 0.25 \\
\hline 2008 & California & Herber South & 10.0 \\
\hline 2008 & California & North Brawley & 50.0 \\
\hline
\end{tabular}

Source: New Energy Finance, 2009.

Electricity generated from geothermal sources reached 15 billion kWh in 2008, representing approximately $0.36 \%$ of the total U.S. electrical production and $12.13 \%$ of electricity generated from renewable resources, excluding hydropower (see Figure 4). ${ }^{11}$

Though growth has been modest, the United States remained the leader in installed geothermal capacity in 2007 (see Figure 5). ${ }^{12}$ Because the majority of electricity production is currently from hydrothermal sources, geothermal power generation in 2008 remained limited to western states that contain these resources (see Figure 6). As more low-temperature and co-produced resources are exploited, geothermal energy is expected to expand eastward (see Figure 7). Additionally, temperatures viable for EGS production are available throughout the U.S. at a depth of $10 \mathrm{~km}$ (see Figure 8), which is reachable with current drilling technology.

Figure 4. U.S. electricity generation by type

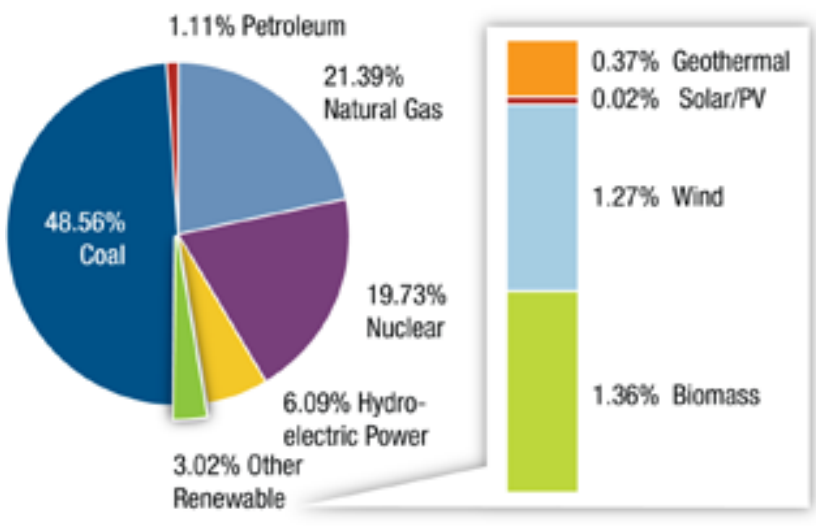

Source: ElA, "Electric Power Monthly" (March 2009)

Figure 5. Top Ten Countries with Geothermal Power Generation (2007)

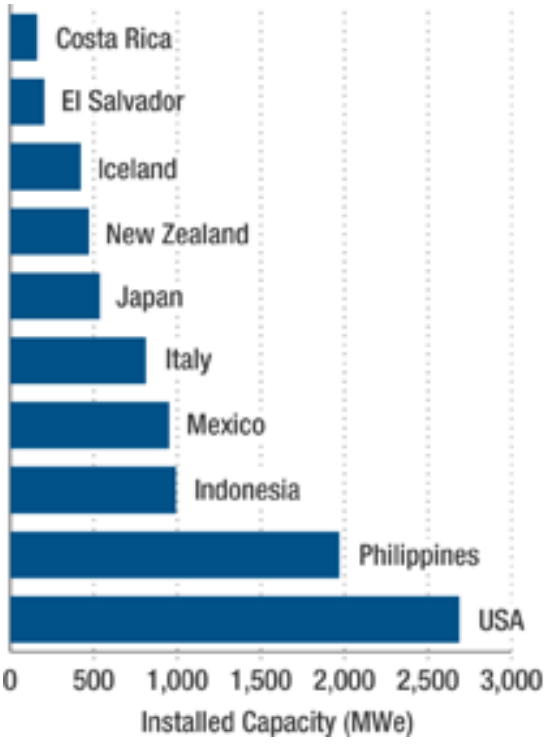

Figure 6. Installed U.S. Geothermal Capacity in 2008

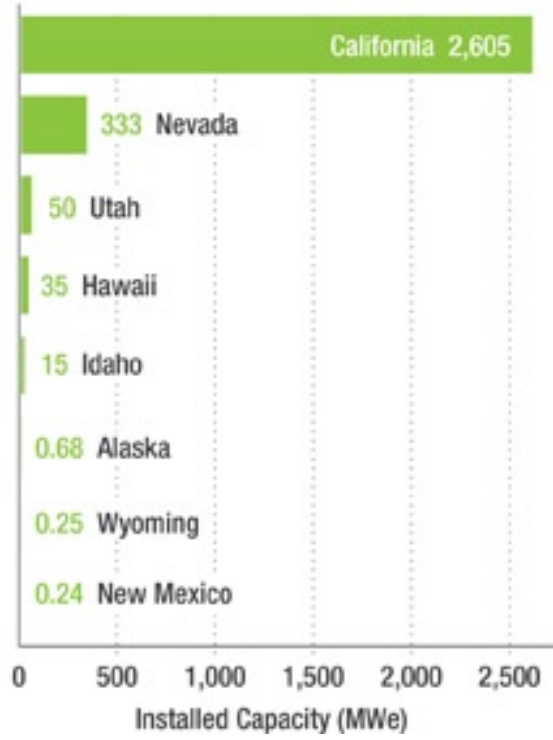

Source (left): Bertani, R. "World Geothermal Generation in 2007" (September 2007)

Source (right): GEA, "U.S. Geothermal Power Production and Development" (March 2009)

\footnotetext{
* Geothermal electricity production can come from resources as low as $74^{\circ} \mathrm{C}\left(165^{\circ} \mathrm{F}\right)$.
} 
Figure 7. Short-Term Geothermal Energy Potential

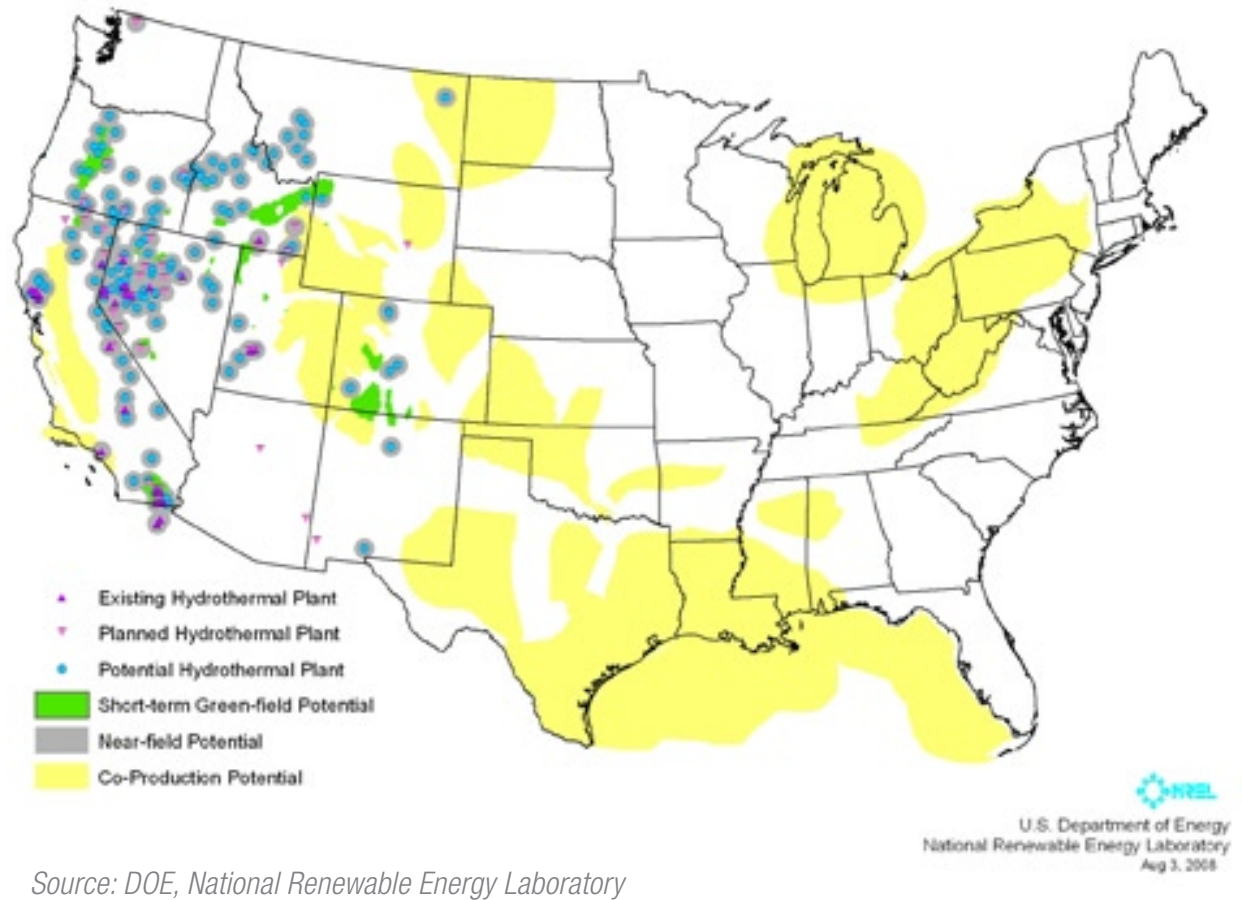

Source: DOE, National Renewable Energy Laboratory

Figure 8. Subsurface Temperatures at 10km Depth - EGS Potential

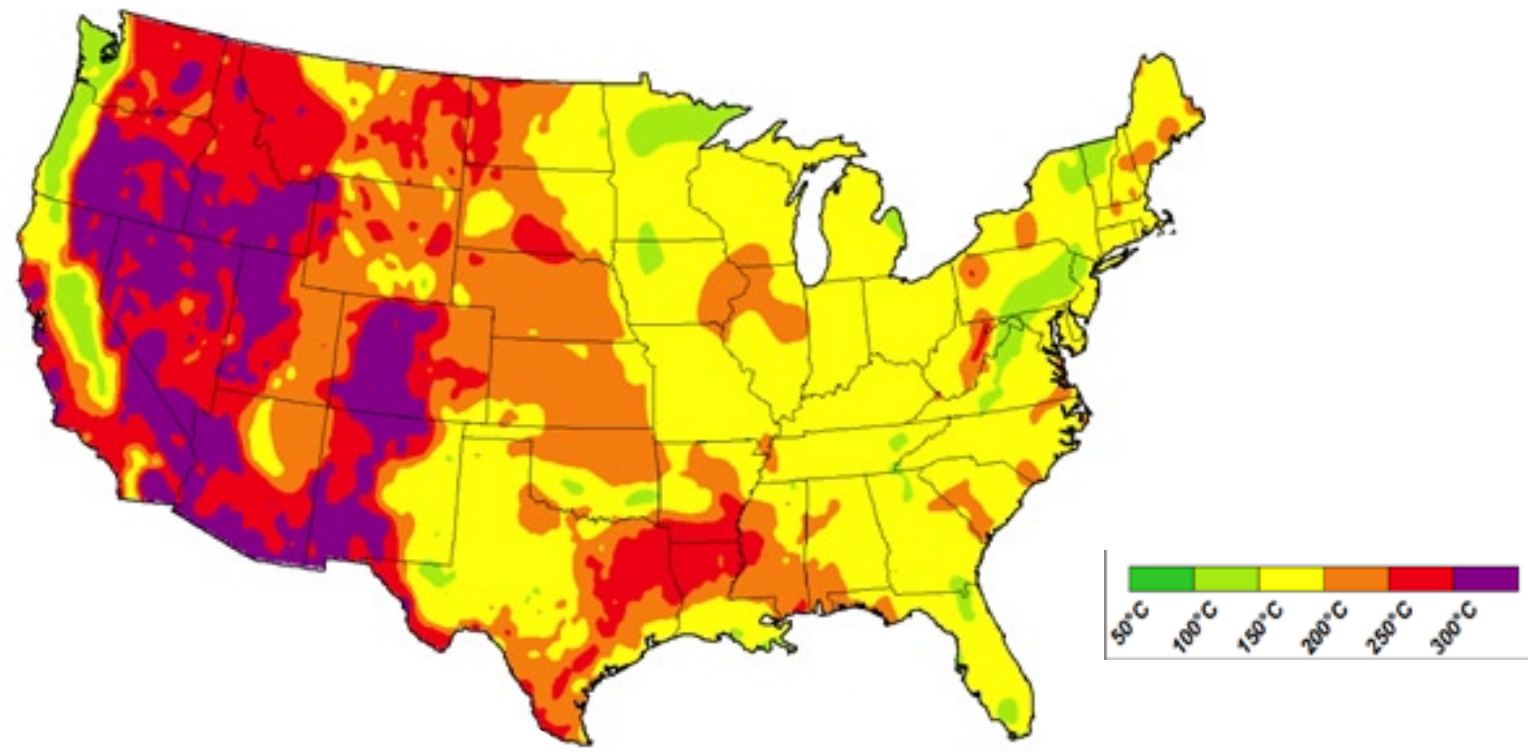

Source: Tester, J., et al. 2006. "The Future of Geothermal Energy: Impact of Enhanced Geothermal Systems (EGS) on the United States in the 21 Century"

\section{USGS Releases the First National Geothermal Assessment in More than 30 Years (September 2008)}

With funding support from Congress and the DOE, the United States Geological Survey (USGS) released an assessment of domestic geothermal electricity production potential in September of $2008 .^{13}$ This assessment focused on electric generation potential in 13 western 
states $^{*}$ and estimated 39,090 MWe of potential from conventional hydrothermal reservoirs. This figure includes 9,057 MWe from discovered sources, and a mean estimated power production potential from 'undiscovered' geothermal resources of 30,033 $\mathrm{MWe}^{\dagger}$ These figures suggest that only $23 \%$ of sources capable of producing geothermal electricity with today's technology have been discovered in the United States. The undiscovered source estimates are based on analysis of the local geology and the calculated potential of current discovered sources in the states examined. The assessment also predicts an additional 517,800 MWe of generation could come from implementing EGS technologies in high temperature, low permeability rock formations (see Figure 9).

\section{The Geothermal Development Pipeline in 2008: 126 Projects with 3,638-5,650 MWe of Capacity}

In August of 2008, the GEA reported that the 103 projects in development ranged from 2,805 MWe to 3,979 MWe in capacity. ${ }^{14}$ By March 2009, the number of projects in development had increased to 126 and an additional 752-1,670 MWe of geothermal generating capacity had been added to the pipeline (see Figure 10). ${ }^{\ddagger}$ According to the GEA, in addition to the eight current western states producing geothermal power, projects exist at various stages in five additional states: Arizona, Colorado, Oregon, Washington and Florida (see Figure 11).

Figure 10. The Geothermal Project Pipeline (2008-2009)

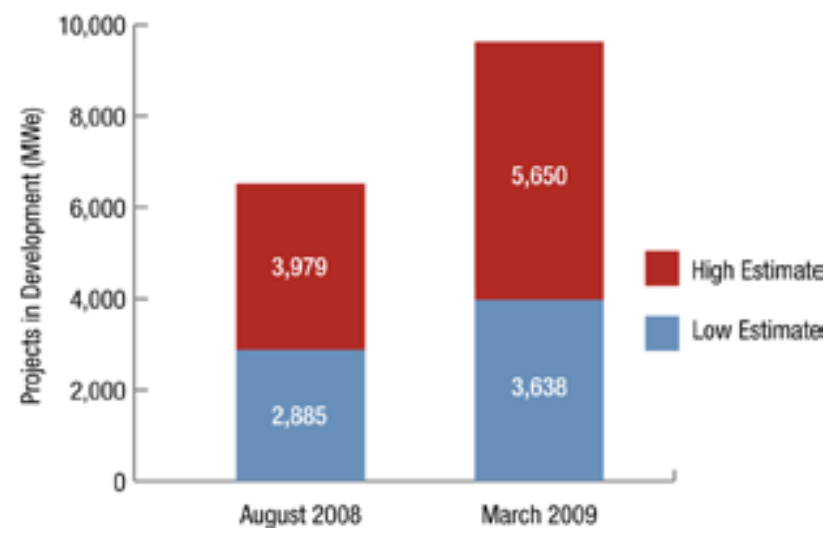

Source: Geothermal Energy Association, "U.S. Geothermal Power Production and Development" (August 2008 and March 2009).

* The 13 states assessed were; Alaska, Arizona, California, Colorado, Hawaii, Idaho, Montana, Nevada, New Mexico, Oregon, Utah, Washington, and Wyoming.

† Figure may be as high as $73,286 \mathrm{MWe}$ at a $5 \%$ probability.

¥ It is important to note that while the overall number of development projects increased, this change in number also accounts for projects that have been completed and removed from the total.
Figure 9. Distribution of Identified, Undiscovered, and EGS Resources

(A) IDENTIFIED

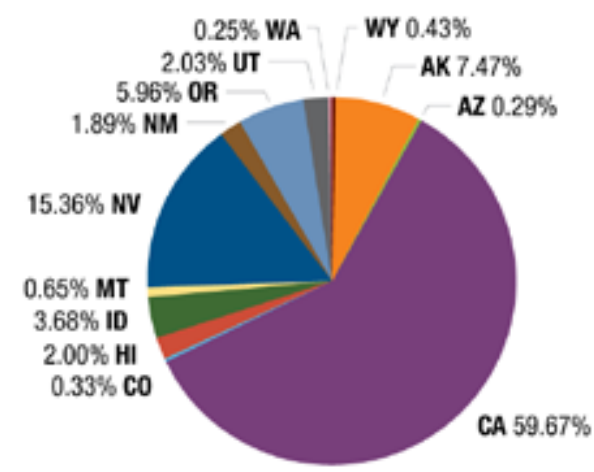

(B) UNDISCOVERED

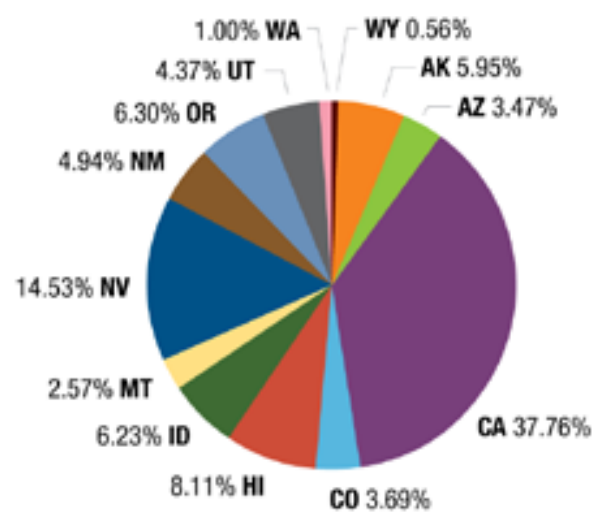

(C) ENHANCED

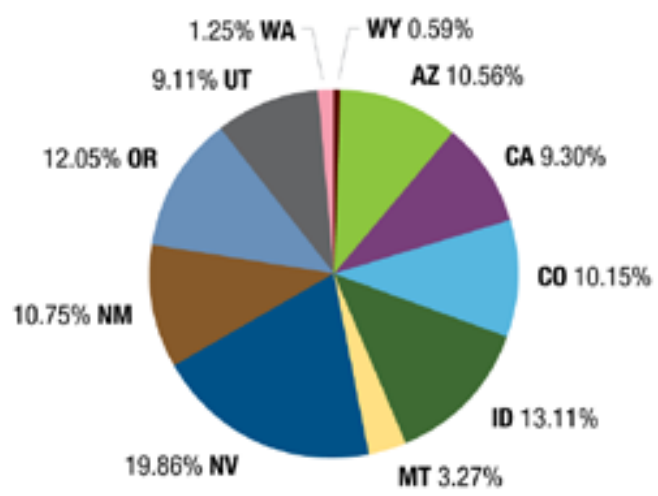

Source: Department of the Interior's BLM, "Assessment of Moderate- and High-Temperature Geothermal Resources of the United States" 2008 
Figure 11. States with Geothermal Projects under Development

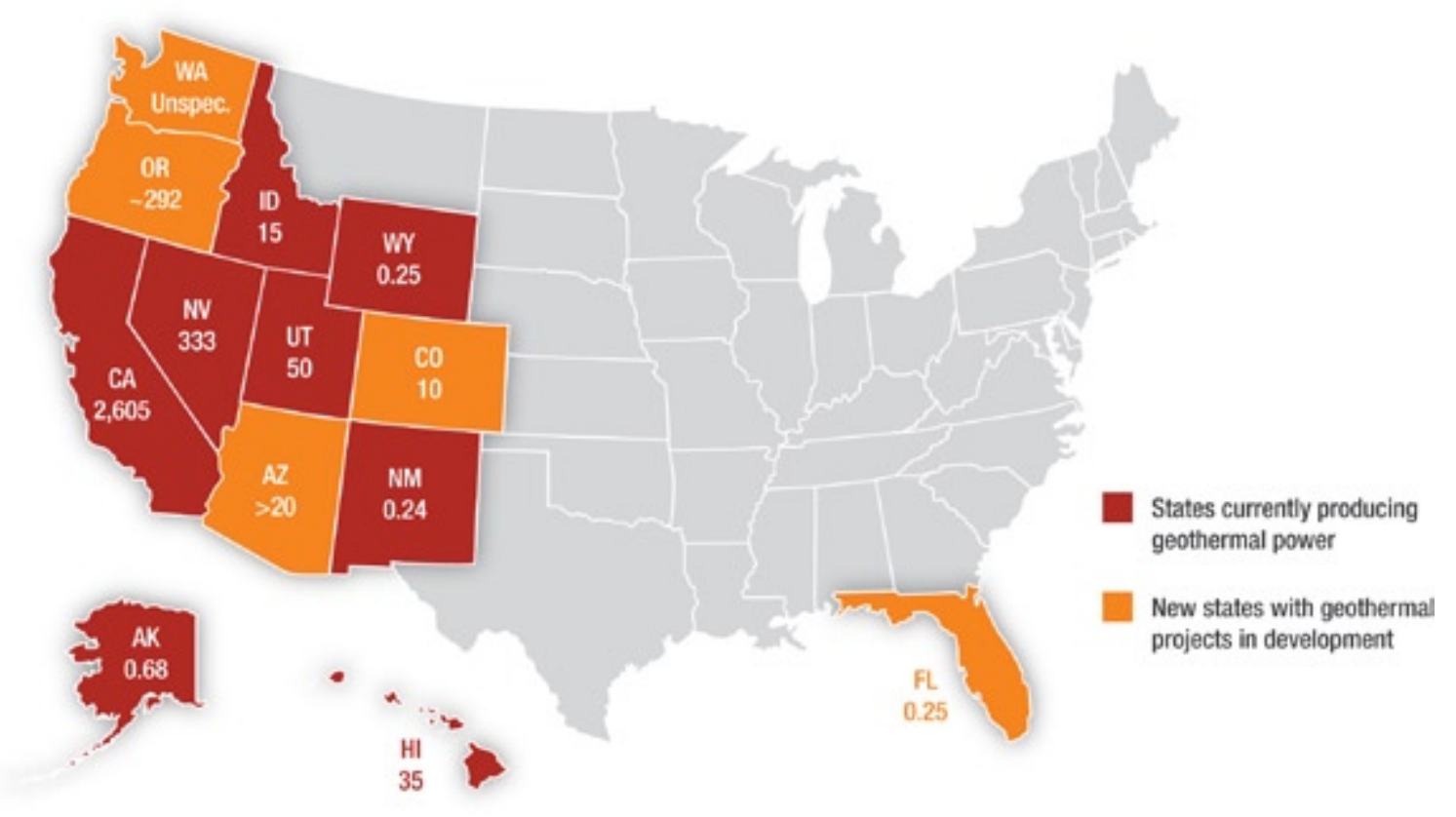

Source: Geothermal Energy Association, "U.S. Geothermal Power Production and Development” (August 2008 and March 2009).

Of the 126 projects in development, ten are currently in the final stages and will add roughly 329-457 MWe of capacity. ${ }^{15}$ As the number of projects under development continues to grow and see completion, the overall installed capacity is expected to bounce back from its 2000 decline (see Figure 12). The decline resulted from a reduction in output from the U.S.'s largest production site, The Geysers Geothermal Field in California. A number of plants were closed due to overproduction of geothermal resources. As the result of recovery measures, some of these plants are now beginning to reopen.

Figure 12: Installed Capacity and Generation, 1960-2007

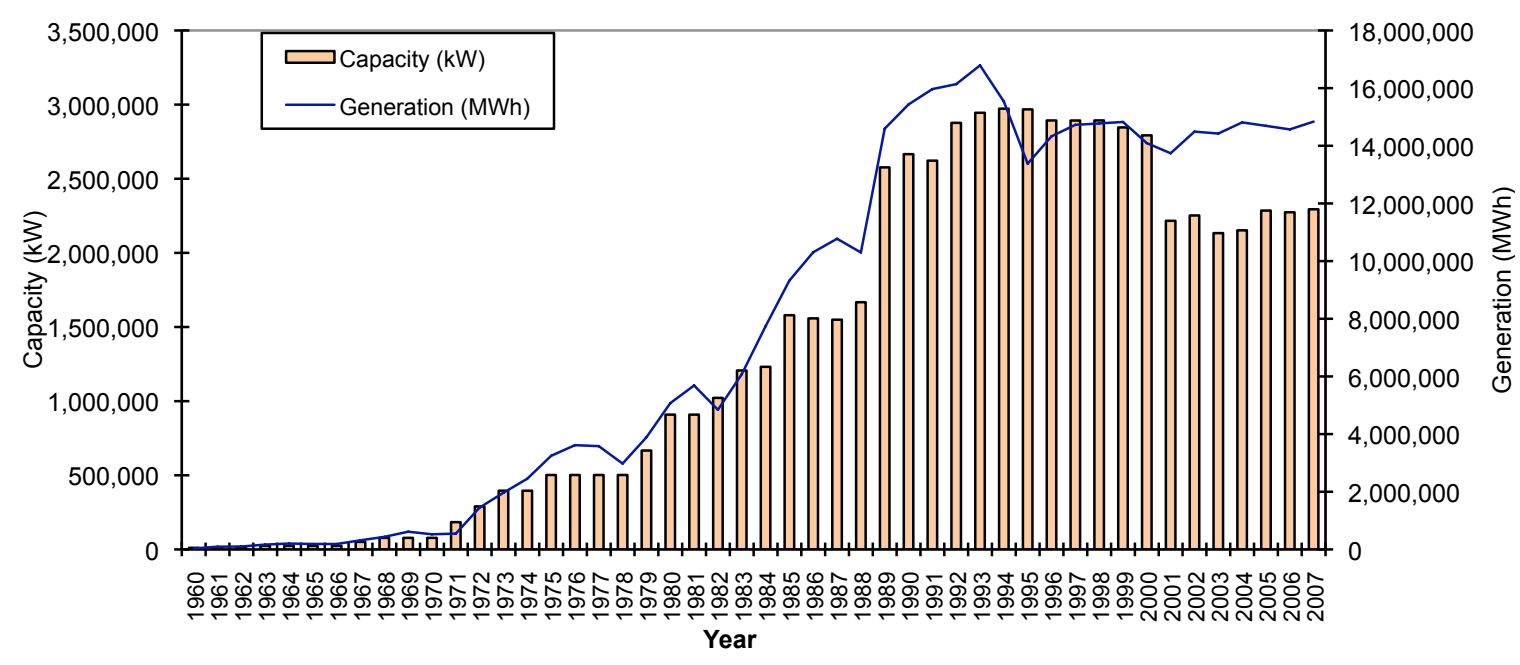

Source: Energy Information Administration (EIA), “Annual Energy Review 2007," June 2008.

* For example, the Bottle Rock Geothermal Power Plant in Cobb, California began operation in 1985, with a 55 MWe capacity. However, the steam field (resource) only allowed for 15 MWe of production. As a result, the operation of the Bottle Rock Power plant was suspended in 1990. Seventeen years later, in 2007, the plant was re-opened and began delivering power to the grid. 


\section{Low-Temperature and Co-Produced Resources are Gaining Ground}

While the majority of geothermal power production comes from conventional hydrothermal sources, the geothermal industry is starting to tap the enormous potential represented by co-produced, geo-pressured and low-temperature resources. In September 2008 at the Naval Petroleum Reserve No. 3 (NPR3), Ormat Technologies and the Rocky Mountain Oilfield Testing Center (RMOTC) achieved the first successful generation of electricity from geothermal technologies integrated with existing oil infrastructure. The Ormat power generating unit known as the Ormat Energy Converter (OEC) has been producing 150-250 gross kilowatts of power since

Figure 13. Ormat's OEC Producing Power From Co-Produced fluids in Wyoming

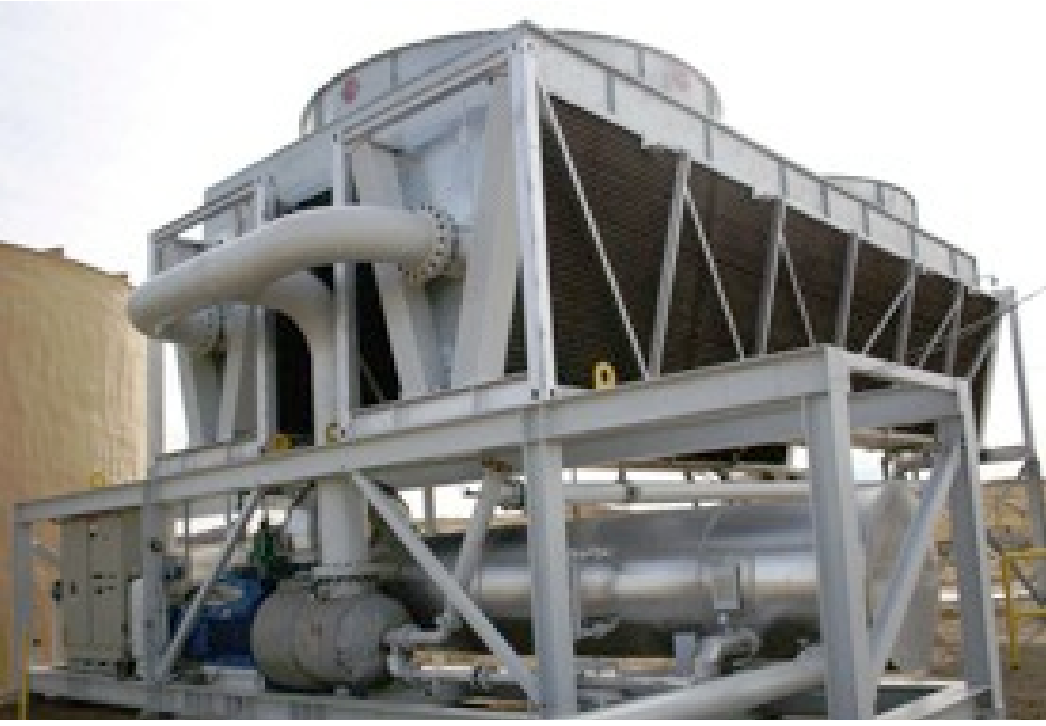

Source: Office of Fossil Energy, "2009 Winter News: Rocky Mountain Oilfield Testing Center its inception (see Figure 13). An average of 40 billion barrels of heated water is co-produced annually from oil and gas wells within the United States; these co-produced fluids have an estimated generation potential of 3,000 to 14,000 MWe, depending on their temperature. ${ }^{16}$ At the Jay Oilfield in Florida another coproduced project is under development, utilizing a UTC Power/Pratt \& Whitney binary generation unit.

Binary units have expanded the resource base for geothermal power by allowing for the exploitation of lower temperature geothermal fluids." Until recently, only temperatures over $93^{\circ} \mathrm{C}$ $\left(200^{\circ} \mathrm{F}\right)$ were deemed commercially viable for successful electric generation from geothermal resources. In 2006 at Chena Hot Springs in Alaska, successful power generation occurred at a temperature of $74^{\circ} \mathrm{C}\left(165^{\circ} \mathrm{F}\right) .^{\dagger}$

Nameplate capacity for binary plants ranges from $200-280 \mathrm{~kW}$ to more than $100 \mathrm{MW}$. The major manufacturers of binary cycle units in use in the United States are UTC Power/ Pratt \& Whitney, which sold approximately 100 of its PureCycle units in 2008, and Ormat Technologies, which sold around 12 of its OEC units in 2008. Other companies that produce binary cycle generators include:

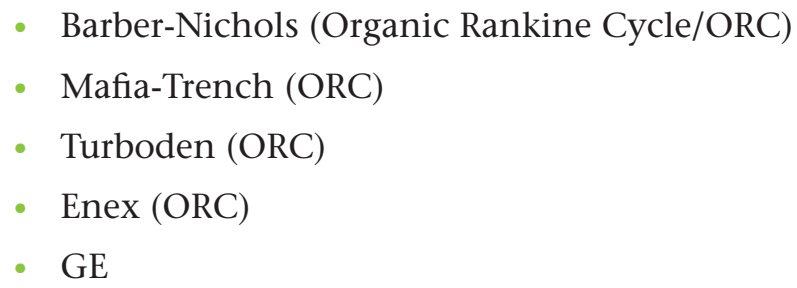

\author{
- Siemens (Kalina Cycle) \\ - Exorka (Kalina Cycle) \\ - Gulf Coast Geothermal \\ ("Green Machine") (ORC) \\ - Deluge Inc. \\ - Linear Power Ltd.
}

\footnotetext{
* In a binary cycle, the heat from a geothermal fluid is transferred to another fluid that vaporizes at a lower temperature and higher pressure than water. The vapor from this second fluid then drives a turbine generator.

† The Chena Hot Springs resort facility used a UTC Power/Pratt \& Whitney PureCycle system. The lowest temperature previously used for commercial energy conversion was $208^{\circ} \mathrm{F}$.
} 


\section{New Binary Plant Designs Reduce Construction Lead Time}

Recently introduced binary-cycle plant designs have allowed power developers to substantially reduce plant construction lead times. One notable example is Raser Technology's Hatch Power Plant in Utah*, completed during November 2008. The plant consists of 50 UTC Power/Pratt $\&$ Whitney PureCycle binary units capable of producing at least $10 \mathrm{MW}$ of net electricity (see Figure 14). The entire project was built and put online in less than one year, with construction completed in just six months rather than the typical three year timeframe.

The project is remarkable not only because of the rapid construction, but also because of the flexibility of its modular approach. Employing small, off-the-shelf UTC Power/Pratt \& Whitney units, a plant can be scaled to the local geothermal resource, energy demand and available financing. Raser has subsequently confirmed that the geothermal resource at Hatch may have the potential to generate more than 200 MW. The company plans to add ten more units in 2009.

Figure 14. Raser's Hatch Power Plant in Beaver Creek, Utah

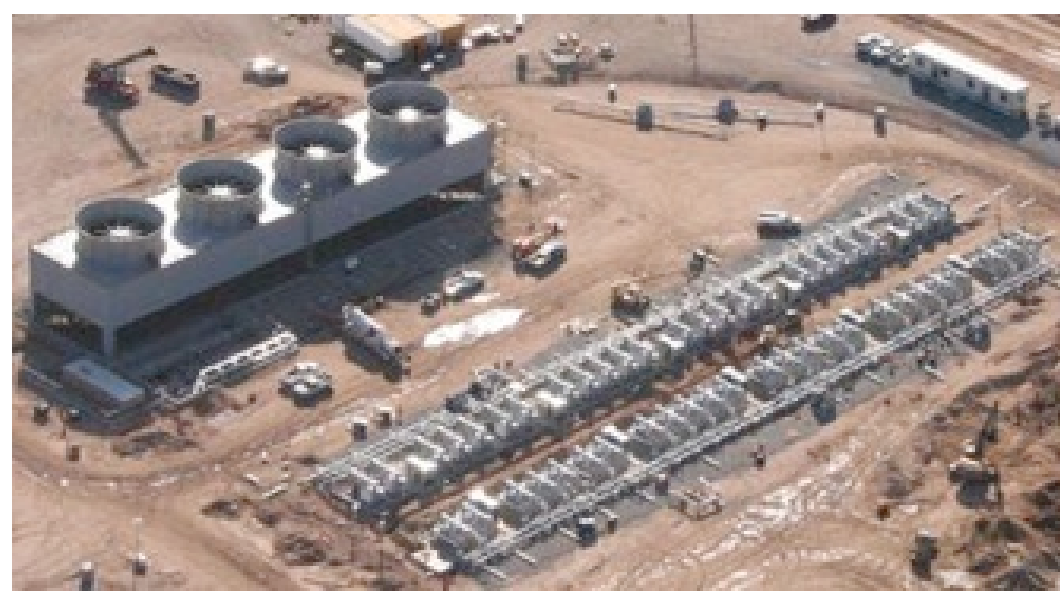

Source: Raser Technologies

\section{DOE-Funded Projects Target EGS Deployment}

The USGS Assessment of Geothermal Resources revealed that the majority of future power generation potential lies with EGS (see Figure 15). However, the technology necessary to exploit EGS resources is not yet commercial-ready. The GTP refocused its long-term technology

Figure 15. Future Geothermal Potential by Resource Category

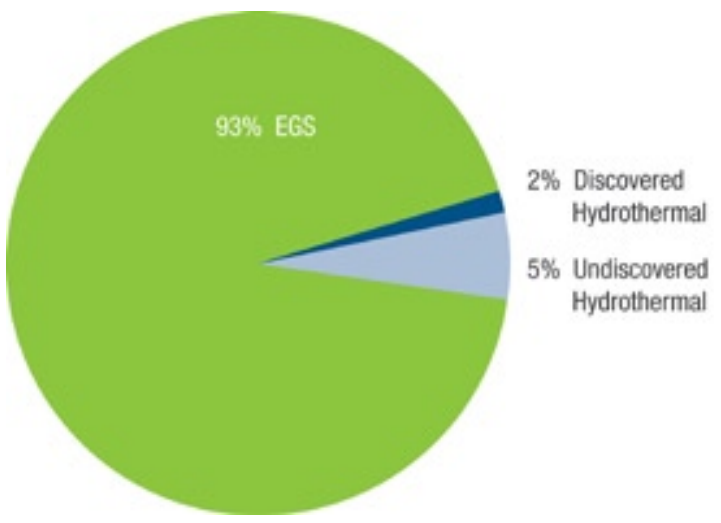

Source: USGS, "Assessment of Moderate- and High-Temperature Geothermal Resources of the United States" development goals to address this state of affairs. The Program selected four field demonstration projects in 2008 focused on EGS reservoir creation, development, management and successful power production. These projects are located on the fringes of pre-existing conventional geothermal fields with active power generating capabilities in order to share infrastructure. Two field projects are located at the Geysers in northern California, run by AltaRock Energy and Calpine. A third project is located at Brady's Hot Springs, Nevada, and the fourth is at Raft River, Utah. ${ }^{17}$

\footnotetext{
* The Hatch Power Plant was formerly known as Thermo.
} 
The four field projects link steam production lines to current power plant facilities on site; no new facilities are under construction. AltaRock will utilize Northern California Power Agency (NCPA) power plants, and Geysers Power Company will utilize their own power plants. The University of Utah will use preexisting plants at the Raft River geothermal field operated by U.S. Geothermal, and Ormat will use their existing power facilities at Brady's Hot Springs. ${ }^{18}$

In addition to AltaRock Energy, Geysers Power Company (Calpine), University of Utah, and Ormat Technologies, other major entities involved in EGS development in the United States are U.S. Geothermal, Inc., APEX Petroleum, Engineering Services, and HiPoint Reservoir Imaging. ${ }^{19}$ 


\title{
Cost of Development, Operation and Maintenance
}

\author{
Conventional Hydrothermal Plants Typically Cost \\ $\$ 3,000$ to $\$ 4,000$ per Installed $K W^{20}$
}

The development of geothermal energy requires the consideration and evaluation of a number of factors, such as site (geography), geology, reservoir size, geothermal temperature, and plant type. In 2008, New Energy Finance published a breakdown of estimated costs for each developmental stage (see Figure 16). The majority of the overall cost is typically attributed to construction of the power plant, due to the high cost of raw materials including steel. The second highest cost intensive processes are the exploratory and production drilling stages, which together comprise $42.1 \%$ of the total cost.

Figure 16. Estimated Developmental Costs for a Typical 50 MWe Geothermal Power Plant

\begin{tabular}{|l|l|}
\hline $\begin{array}{l}\text { Developmental } \\
\text { Stage }\end{array}$ & $\begin{array}{l}\text { Cost (\$ per } \\
\text { kW installed) }\end{array}$ \\
\hline Exploration & 14 \\
\hline Permitting & 50 \\
\hline Steam Gathering & 250 \\
\hline Exploratory Drilling & 169 \\
\hline Production Drilling & 1,367 \\
\hline Plant \& Construction & 1,700 \\
\hline Transmission & 100 \\
\hline Total & $\mathbf{3 , 6 5 0}$ \\
\hline
\end{tabular}

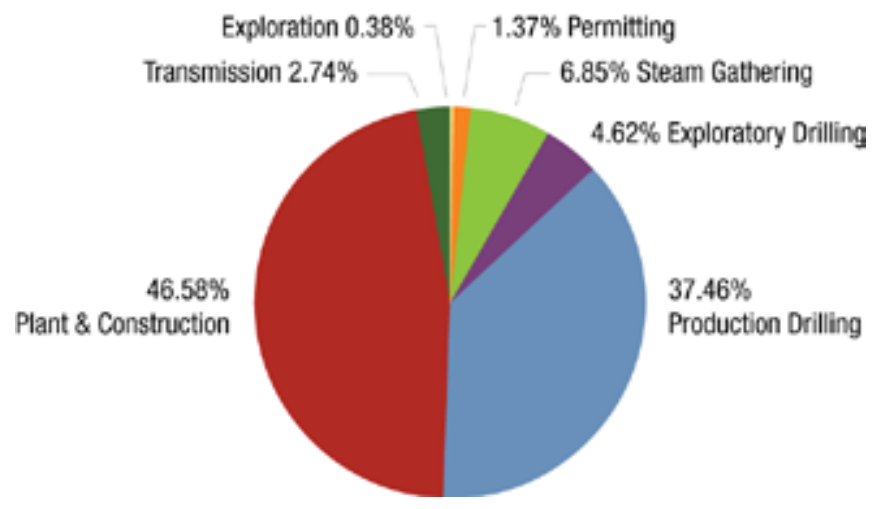

Source: Taylor, M. New Energy Finance, 2009

Though geothermal power production is very capital-intensive with high first-cost and risk, it boasts fairly low operating costs and a high capacity factor ${ }^{*}$, making it one of the most economical baseload power generation options available. As previously noted, a number of factors contribute to the cost of developing a geothermal power plant. The power conversion technology (plant type) in use also has an effect on cost. Low-temperature reservoirs typically use binary power plants, while moderate- to high-temperature reservoirs employ dry steam or flash steam plants, based on whether the production wells produce primarily steam or water, respectively. Recent cost comparisons between flash, dry steam and binary plants do not demonstrate a clear winner. ${ }^{21}$

* Capacity factor measures the amount of real time a facility is utilized to generate power. 


\section{Power Plant Construction Costs Decline In 2008}

After years of steady increases in plant construction costs, 2008 saw a 5\% decline, according to Cambridge Energy Research Associates (CERA) (see Figure 17). Additional cost reductions of approximately 7\%-10\% are expected for 2009 due to the declining worldwide economy and sharp cost reductions for raw materials, including steel and copper. Steel prices fell nearly $30 \%$ in the fourth quarter of 2008, a backlash from steep increases in the beginning of the year. Availability of equipment such as drilling rigs, labor, engineering and management services, has also improved due to delays and cancellations of other new plant construction projects. While some power purchase agreements were renegotiated to reflect higher overhead prices in 2008 , some utilities may postpone negotiations and wait for costs to decrease. ${ }^{22}$

Figure 17. IHS/CERA Power Capital Costs Index (PCCI)

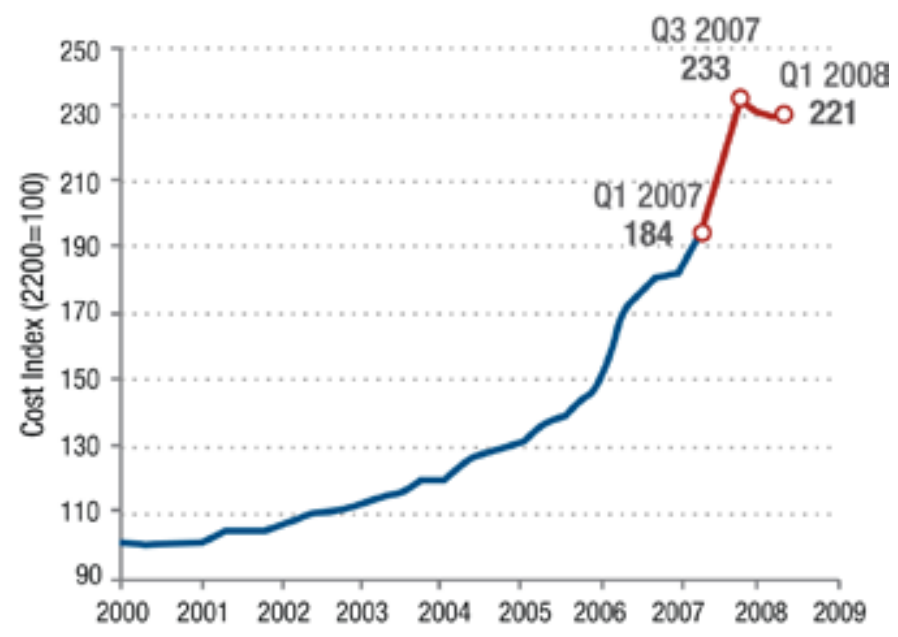

Source: Cambridge Energy Research Associates

\section{Geothermal Development Cycle and Risk Profiles}

Sizable up-front capital requirements, pervasive resource and development uncertainty, and long project lead times lead to risk-related mark-up over other renewable and traditional energy alternatives. These factors, combined with current economic conditions, mean private firms seeking to develop geothermal projects may face greater difficulties in obtaining the requisite capital for exploration and development. Industry analysts suggest that although financing is still available, the terms will be less attractive to investors and developers. ${ }^{23}$ Nevertheless, equity investors see real opportunity in the sector.

\section{Development of Geothermal Power: Project Cycle}

The primary stages of the geothermal development cycle are exploration, resource confirmation, drilling and reservoir development, plant construction and power production. Each of these steps carries with it different varieties and levels of risk. As Figure 18 shows, the risks associated with each stage call for different types of equity investors, who will expect a reward commensurate with the level of risk they assume. 
Figure 18. The Geothermal Development Cycle

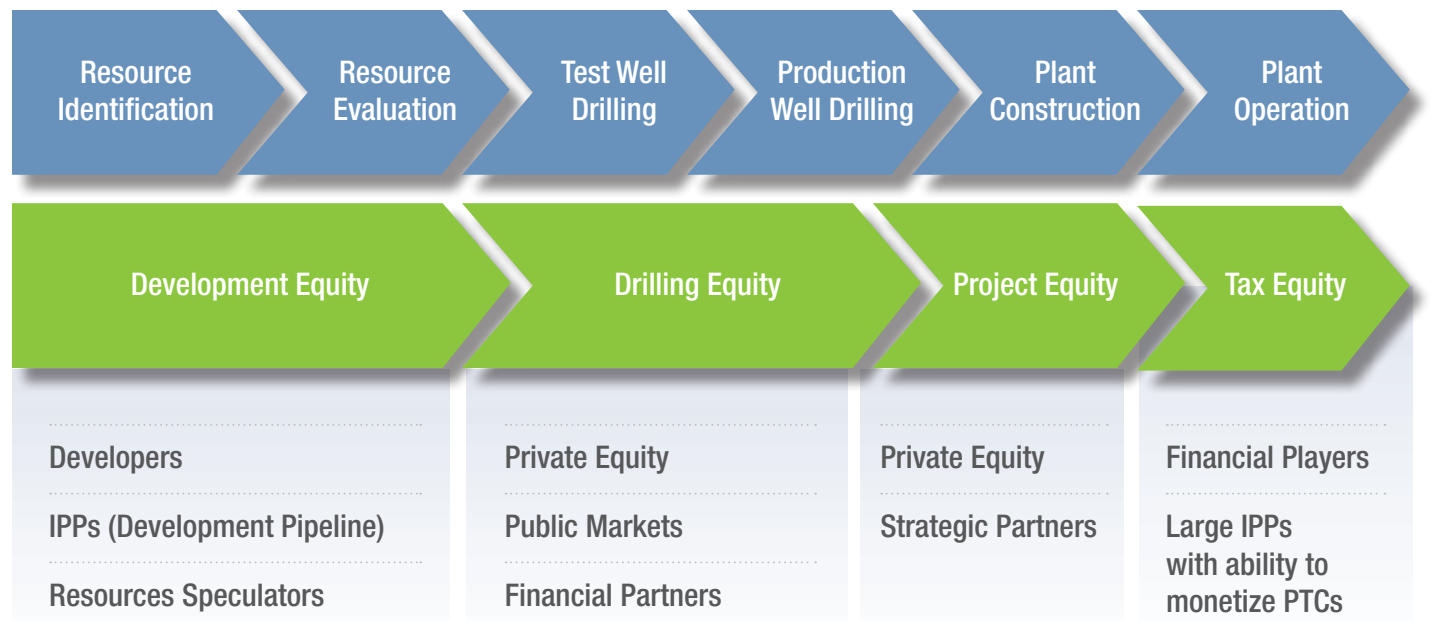

Source: Geothermal Investment: An Equity Provider's Perspective, Geothermal Investors' Forum, October 2007

Though geothermal projects vary widely in terms of technical elements, location, and economic and political environments, financial models employed are relatively consistent. The greatest risk is associated with the initial stages of development, prior to the verification of the geothermal resource (see Figure 19). Activities such as the drilling of exploratory wells may prove unsuccessful even if geological data are favorable. Additionally, cost and risk increase proportionately with drilling depth. As the project moves toward the production phase, this risk begins to decline and financing options are more readily available.

Figure 19. Risk and Financing for Each Phase of Project Development

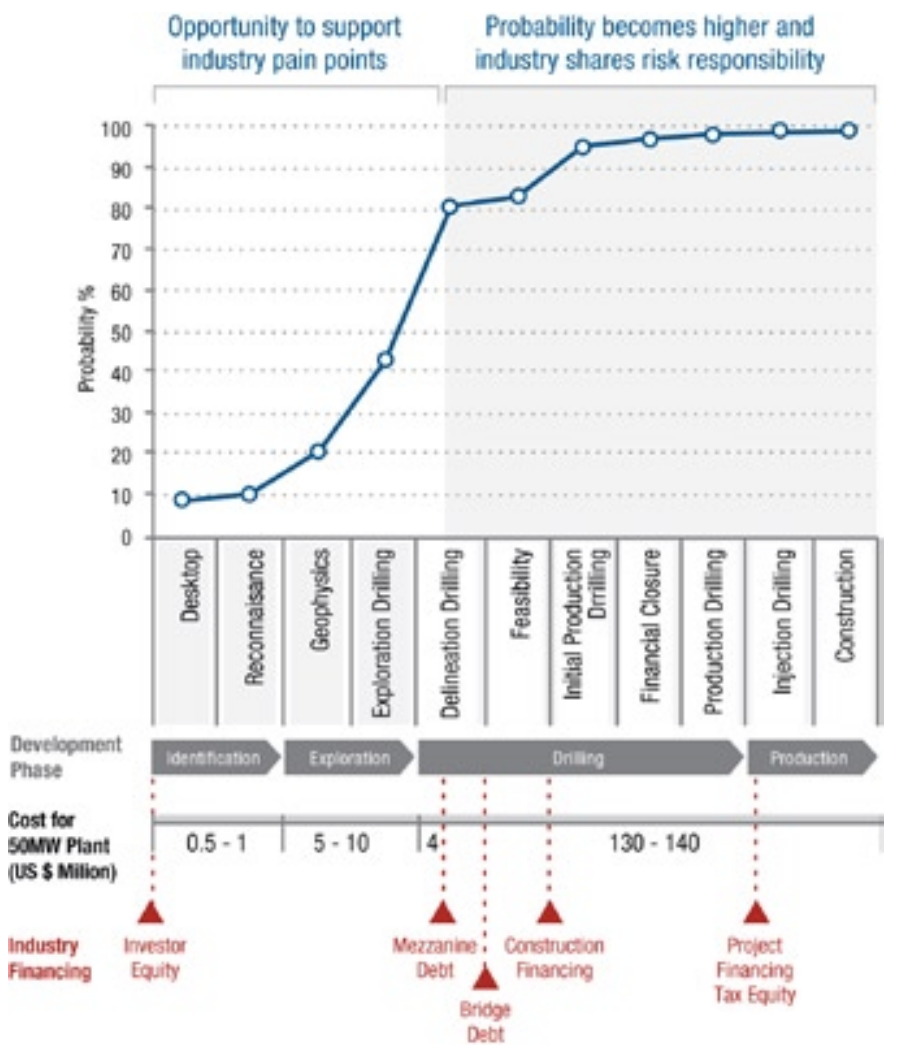


In the exploration stage, prior to the validation of the geothermal resource, equity financing predominates, usually in the form of seed or venture capital. The project developer may also fund a portion out of its own budget. Debt financing, i.e., bank loans, typically enters the investment cycle following the successful demonstration of the geothermal resource, when the risk is greatly diminished. Though the costs associated with exploration and resource confirmation only account for approximately $10 \%$ of overall project costs, the risk associated with these activities is still too high for traditional debt lenders. Power developers have identified strategies to address the risk inherent at each development stage (see Table 5).

Table 5. Geothermal Project Risk Mitigation Strategies

\section{PROJECT RISK}

\section{Exploration Stage}

Lack of heat or fluid for heat extraction. A $25 \%$ success rate.

\section{Resource Capacity Risk}

$70 \%$ drilling success risk

\section{Regulatory Risk}

Minimal with the proper planning

\section{Drilling Risks}

Risk of drilling a dry well, approximately $70 \%$ success risk

\section{Plant Construction Risk}

There is minimal risk if the previous items

are completed appropriately.

\section{Financing Risk}

Financing issues for independent developers include: exploration financing (investor may want returns equal to multiples of investment), require an investment-grade power purchaser, construction financing (interest rates may be up to $10 \%$ or more, construction lender requires "take out" guarantee at commissioning), term financing usually based on $30 \%$ equity $/ 70 \%$ debt, IRR in the high teens, interest $7 \%$ or more for 15 years.

\section{MITIGATION STRATEGY}

Make maximum use of surface technologies,

Go-No Go exploration steps

Drill and test deep wells, develop a rigorous resource model.

Utilize an experienced permitting consultant, begin the process early

Prepare geological model and drill with blow out protectors and control of well insurance. Create a "risk fund" that can mitigate investor drilling risk during the exploration, confirmation project stages.

Use a credible supplier/contractor, get turnkey fixed price/date certain contract, use fieldproven technology supplier, get start-up performance guarantee.

Execute financeable take or pay PPA with utility, execute binding commitment with lender

\section{Tax Equity Financing - Special Purpose Entities and the Partnership Flip}

The third major source of capital available to the geothermal project developer is tax equity financing, monetized through the creation of a special purpose vehicle (SPV) ${ }^{*}$ and what is commonly known as a partnership flip. Federal tax subsidies amount to a large share of development financing for a variety of types of renewable energy plants, including solar, wind and geothermal. Geothermal projects qualify for the Federal PTC under Section 45 of the Internal Revenue Code (IRC), a 2.1 cent per kWh credit claimed on the electricity generated 
by the geothermal plant for up to 10 years. The geothermal developer may also depreciate the geothermal property over five years, allowed under the Modified Accelerated Cost-Recovery System (MACRS). In addition, intangible drilling costs can be deducted immediately, either amortized over the five-year period or folded into basis in the geothermal wells and reservoirs, and depletion can be claimed on the investment in the reservoir. ${ }^{24}$ In sum, a substantial portion of the cost of developing the geothermal project can be covered by these tax benefits.

To claim the credits under Section 45 of the IRC, the taxpayer must be the owner and operator of the renewable energy property, but most developers cannot directly utilize these tax subsidies to build their projects. The trick is to monetize them or convert them into capital through a partnership flip. Under this arrangement, the geothermal developer brings in an outside entity, typically a large, institutional investor that can take advantage of the available tax credits, forming a special purpose entity or vehicle. The developer enters into a disproportionate allocation partnership with this investor, an arrangement made for tax purposes wherein the party attempting to monetize the tax credits is allocated the majority share of project income and loss. The tax-oriented investor is allocated $99 \%$ of the geothermal plant's economic returns, i.e., income and tax credits, until they reach a target yield--an aftertax return on investment previously agreed upon by both parties. This is typically designed to occur towards the end of the 10-year tax credit period, once the project is completed and in operation, providing a revenue stream. On this flip date the investor's percentage interest is reduced to $5 \%$ and the developer has the option to buy the remaining interest. That is, the project flips back to the developer. ${ }^{25}$

The total tax equity generated against the project at the outset of such a partnership arrangement is essentially the present value of cash income, PTCs, depreciation-related tax savings, depletion interest and investor-paid intangible drilling cost deductions and taxes. The amount of tax equity depends upon the overall capital cost of the project, the quantity of electricity generated, negotiated prices under the power purchase agreement with the end user, and the tax equity yield. For every 50 basis point increases in yield, the portion of plant cost covered by the tax credits is reduced by approximately $10 \%$. That is, with each hike in yield the equity investor is providing less value in return for the tax credits. At some point, it may be beneficial for the project developer to retain the tax benefits for its own future use. ${ }^{26}$ To qualify for the production tax credits, geothermal projects must be placed into service by December 2010, though plants that come online after this date are still eligible for a $10 \%$ investment tax credit (ITC). The developer may utilize tax equity financing at the initiation of the project or, if it has access to sufficient debt financing during the plant construction phase, it may opt to sell the tax-oriented investor an interest in the project after it has started operating.

\section{Availability of Geothermal Project Financing Declines in 2008}

The current global economic crisis impacts the ability to obtain tax equity for such partnership flip scenarios, which require the resources of large institutional investors, such as Morgan Stanley, GE Financial Services, and the now-bankrupt Lehman Brothers. This sector has contracted rapidly over the last six months. According to industry analysts, just half of the 14 large financial companies that funded renewable energy projects over the past two years are still active in this market, resulting in a \$2-3 billion tax equity shortfall at the close of 2008. Tax equity yields are 150-170 basis points higher than just one year ago. ${ }^{27} \mathrm{~A}$ representative of GE Financial Services was recently quoted as saying that the firm simply did not have the resources to take on any new tax-monetization investments in renewable energy projects. ${ }^{28}$ Finally, the increased borrowing costs and tax equity yields may even require developers to renegotiate power purchase agreements with their utility customers. ${ }^{29}$ 
As fewer financiers are active in the markets, there are limited financing options available for geothermal companies, more stringent financing terms and added deal-making complexity. ${ }^{30}$ Development capital that is still available will tend to gravitate to renewable energy projects that demonstrate the greatest potential for project returns for a given level of risk. ${ }^{31}$ Resource uncertainty, high up-front capital cost and attendant risk associated with geothermal energy production could potentially handicap new projects currently in the pipeline for the sector. Developers may be required to drill additional boreholes to secure up to $50 \%$ of capacity rather than the $30-35 \%$ that was previously sufficient, increasing up-front costs as much as $\$ 20$ million. ${ }^{32}$ Debt providers generally require that $25 \%$ of the resource capacity is proven and a long-term PPA in place prior to lending. ${ }^{33}$ There are numerous reports of geothermal projects on hold for want of financing in early 2009. ${ }^{34}$

Geothermal companies that have advanced to the later project stages, with available cash and liquidity, are surer bets for investors because they have greater flexibility to develop their projects. They might be able to rely on the strength of their balance sheets to finance projects outright or use them to obtain better deals from investment partners. Ormat, despite a significant decline in its stock from a 2008 high of $\$ 53.54$ to $\$ 38.18$ (quoted May 27, 2009), remains in this category of developers. On the other hand, small or inexperienced developers, with limited project portfolios or projects in the early exploration or drilling stages, will be severely impacted. For example, Sierra Geothermal Power (SGP), currently active with five exploration-stage projects in Nevada, has run low on available working capital and such a weak hand to show to investors hinders its ability to attract new capital. ${ }^{35}$

\section{Geothermal Costs Less Than Other Renewables and Some Conventional Sources}

Geothermal power production boasts fairly low operating costs and high capacity factor, making it one of the most attractive baseload generation options available among renewables. On a levelized cost of energy (LCOE) basis*, which provides an apples-to-apples comparison of generation options, geothermal is very competitive with other renewable and conventional technologies. Most recently, the financial advisory and asset management firm, Lazard, calculated LCOE for various alternative and conventional electric generating technologies. With tax incentives included, it estimated geothermal LCOE between $\$ 0.042$ and $\$ 0.069$ per kWh depending on technology employed (See Figures 20). An earlier 2005 study conducted by the California Energy Commission estimated geothermal LCOE between $\$ 0.04$ and \$0.09 per kWh with PTCs added (See Table 6). Despite the high upfront cost and risk, geothermal installation costs are lower than nuclear, solar, small hydro, and selected biomass technologies. ${ }^{36}$

Table 6: LCOE for Various Geothermal Generation Technologies (\$/kWh)

\begin{tabular}{|l|c|c|}
\hline Technology & Without PTC & With PTC \\
\hline Dry steam & $\$ 0.0781$ & $\$ 0.0691$ \\
\hline Dual flash steam & $\$ 0.0563$ to $\$ 0.0979$ & $\$ 0.0473$ to $\$ 0.0889$ \\
\hline Binary & $\$ 0.049$ to $\$ 0.1021$ & $\$ 0.040$ to $\$ 0.0931$ \\
\hline
\end{tabular}

Source: California Energy Commission, "Geothermal Strategic Value Analysis, June 2005.

* LCOE includes a more complete set of cost variables, including fixed and variable costs, financing and fuel costs. It is defined as a constant annual costs that equivalent on a present-value basis to the annual costs, which may be variable. It may include capital and financing costs, insurance costs, ad valorem/property tax costs, fixed and variable operations and maintenance costs, corporate taxes, and costs of fuel. (Comparative Costs of California Central Station Electricity Generation Technologies, California Energy Commission Report CEC-200-2007-011 SF, December 2007) 
The costs to develop a given geothermal plant can vary tremendously depending on resource characteristics, the conversion technology utilized by the plant, and other factors, such as raw materials, drilling, and financing costs. It should also be noted that PTCs play a major role in making geothermal more competitive (see Figure 21). Without Federal tax incentives, costs can soar to between $\$ 0.078$ and $\$ 0.116$ per $\mathrm{kWh}$, highlighting the importance of these incentives (see Table 8 and Figure 21). ${ }^{37}$ In 2008, the PTC for geothermal was $\$ 0.021$ per $\mathrm{kWh} .{ }^{38}$

Figure 20. Levelized Cost of Energy per MWh of various power technologies

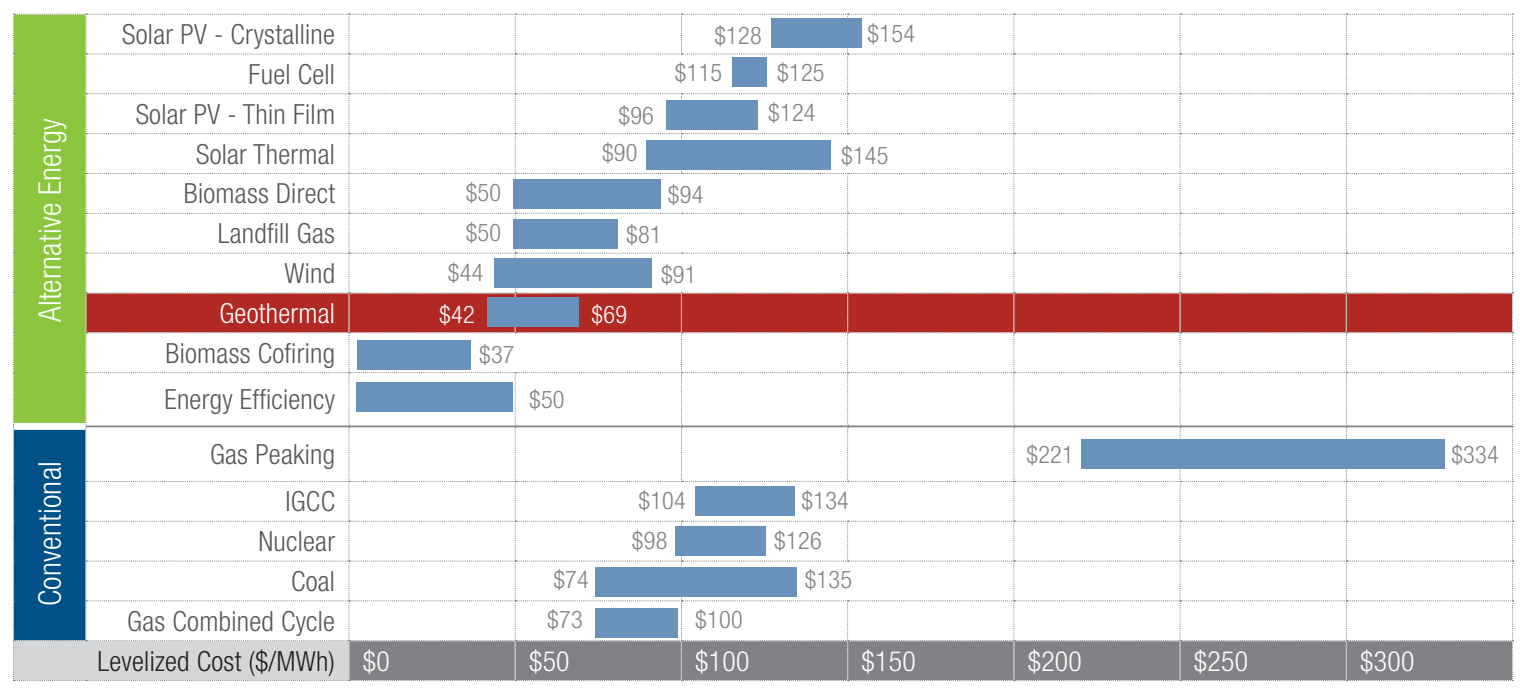

Source: Lazard, June 2008

Figure 21: Levelized Cost of Renewable Technologies With and Without Tax Incentives

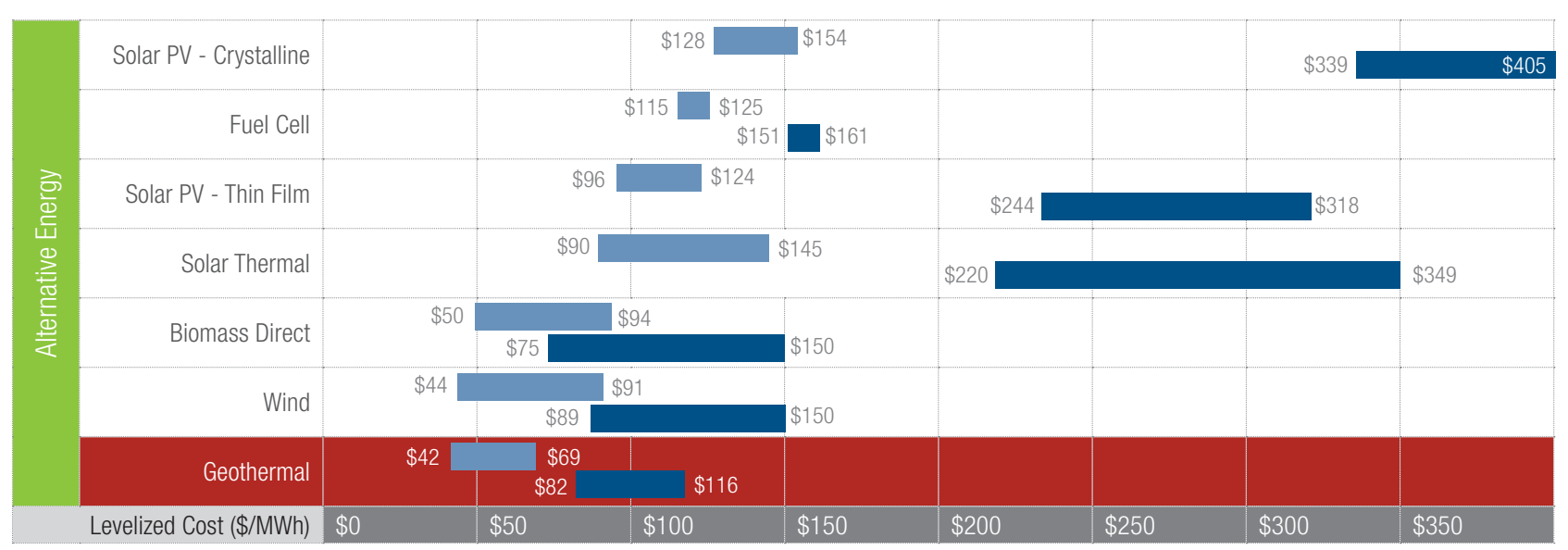

Source: Lazard, June 2008 


\section{National Policy, \\ Geothermal Leasing and Permitting}

\section{EESA of 2008 Extends Geothermal Tax Incentives}

On October 3, 2008, President Bush signed the EESA of 2008 (H.R. 1424), which included the Energy Improvement and Extension Act of 2008. The bill extended PTCs for electricity produced by geothermal facilities (as well as other renewable energy sources) by two years, bringing the sunsets of these credits to the end of 2010. This brought a renewed sense of certainty to the investment market, as these tax credits were set to expire at the end of 2008 . This act also created a 30\% tax credit for GHPs, with a cap of $\$ 2,000 .{ }^{39}$

\section{Renewable Portfolio Standards Drive Renewable Energy Development}

Renewable Portfolio Standards (RPSs) are widely considered to be an essential driver for development of geothermal and other renewable energy technologies. Currently, RPSs exist only at the state level in the United States. The diverse set of authoring entities has resulted in a disparate set of policies governing geothermal technologies. Many of the state RPSs target small-scale or residential geothermal projects, but do not provide adequate incentives for large-scale exploration or plant development. As of May 2009, 32 states and Washington, D.C. have implemented RPS guidelines that are either mandatory or goal-oriented (see Figure 22). A national RPS is currently under consideration in Congress (see "Looking Ahead" section for more detail).

Figure 22. States with Renewable Portfolio Goals and Policies
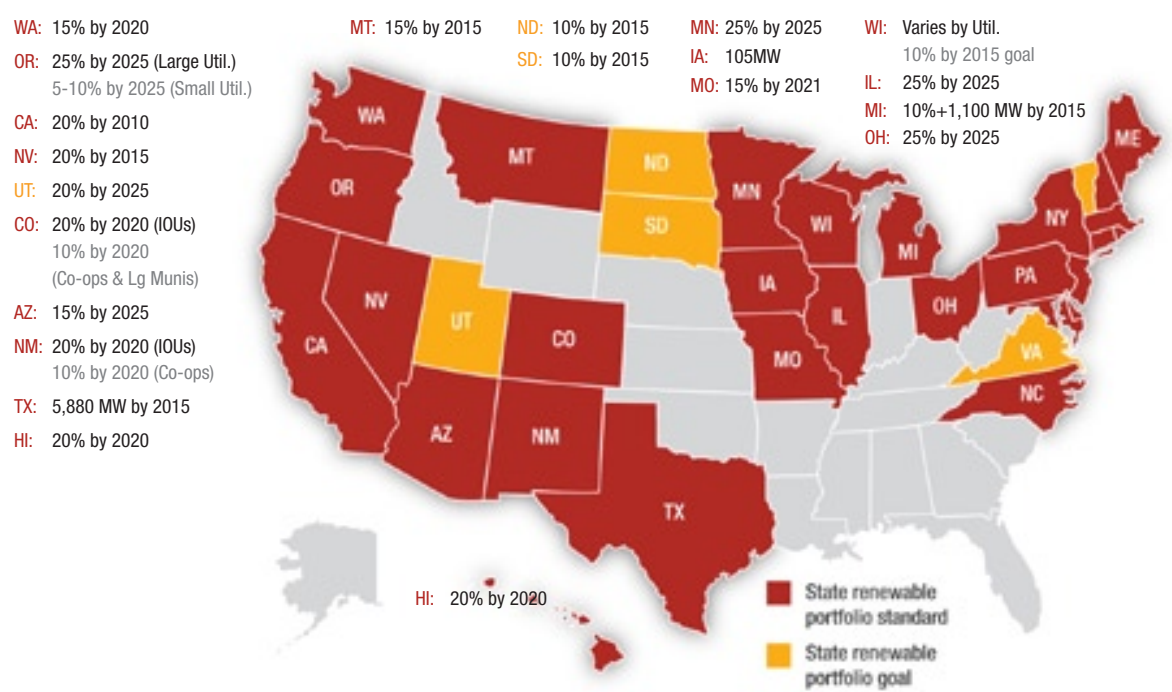
ME: $30 \%$ by 2000 New RE: $10 \%$ by 2017
NH: $23.8 \%$ by 2025
$V T$ : (1) RE meets any increase in retail sales by 2012

A: $15 \%$ by 2020

$+1 \%$ annual increase (Class I Renewables)

RI: $16 \%$ by 2020

CT: $23 \%$ by 2020

NY: $24 \%$ by 2013

NJ: $22.5 \%$ by 2021

PA: $18 \%$ by 2020

DE: $20 \%$ by 2019

MD: $20 \%$ by 2022

DC: $20 \%$ by 2020

VA: $15 \%$ by 2025

NC: $12.5 \%$ by 2021 (IOUs) $10 \%$ by 2018 (Co-ops \& Munis) 


\section{Western Renewable Energy Zone to Expedite Renewable Energy Development and Delivery}

The Western Renewable Energy Zone (WREZ), an initiative launched in May 2008 by the Western Governors' Association and DOE, seeks to identify the most cost-effective and environmentally sustainable areas within the western United States to develop renewable energy resources and facilitate their delivery to major load centers. The project promotes stakeholder collaboration and information exchange between state and Federal governments and non-governmental organizations with a regional approach to energy development. Eleven states, two Canadian provinces, and areas in Mexico that are part of the Western Interconnection are currently participating in the project.

\section{EPAct 2005: New Procedures for Federal Geothermal Leases}

BLM manages over 700 million acres of subsurface mineral estate and through 480 leases has made just 700,000 acres available for geothermal development, highlighting the vast potential for development of domestic geothermal energy. ${ }^{40 / 41}$ The Energy Policy Act (EPAct) of 2005 addressed the growing backlog of lease applications by fostering greater cooperation among the Federal agencies involved in the leasing process. The BLM and the Forest Service signed a memorandum of understanding (MOU) in 2006 that lead to the completion of the Programmatic Environmental Impact Statement (PEIS), which amends federal resource management plans and land use plans. Site-specific analysis of leasing nominations, permit applications, and operations plans can refer back to the PEIS, reducing the processing time for leasing and permitting.

\section{BLM Expands Geothermal Leasing}

On December 17, 2008, BLM released its Record of Decision for Geothermal PEIS signed by the Department of the Interior's Assistant Secretary for Land and Minerals Management. This decision (1) allocates BLM lands as open to be considered for geothermal leasing or closed for geothermal leasing, and identifies those National Forest System lands that are legally open or closed to leasing; (2) develops a reasonably foreseeable development scenario that indicates a potential for 12,210 megawatts of electrical generating capacity from 244 power plants by 2025, plus additional direct uses of geothermal resources; and (3) adopts stipulations, best management practices, and procedures for geothermal leasing and development.

BLM held a competitive auction of lease parcels on August 5, 2008 in Reno, Nevada, offering 35 parcels encompassing a total of 105,211 acres. The lease sale brought in a record $\$ 28.2$ million in bids for geothermal energy development. A second lease sale was held in December 2008 offering 61 parcels totaling 196,377 acres in the states of Utah, Oregon, and Idaho. Cumulatively the two sales totaled 301,588 acres and generated more than $\$ 34.5$ million in revenue. 


\section{Direct-Use and GHPs}

\section{Direct-Use \& GHPs: Strong Market Growth in 2008}

Direct-use applications typically include aquaculture, greenhouses, industrial and agricultural processes, pools and spas, and space and district heating. Direct use of geothermal energy consumed 0.0094 quadrillion BTUs (quads) in 2007 (see Figure 23).* In 2008, the installed capacity for direct uses, excluding heat pumps, was estimated to be $704 \mathrm{MWt}$ with an annual consumption of 10,332 TJ/yr (2,869 GWh/yr) using an overall escalation of 4\%. ${ }^{\dagger}$ All non-heat pump direct uses had a calculated capacity factor of 46 percent, identical to past-calculated values. ${ }^{42}$ While a projection has been made for 2008, direct-use estimates are difficult to determine because there are a wide array of uses, locations are geographically diverse, and temperature and flow-rates are unknown. ${ }^{43}$

Figure 23. Geothermal direct use of energy (1990-2007)

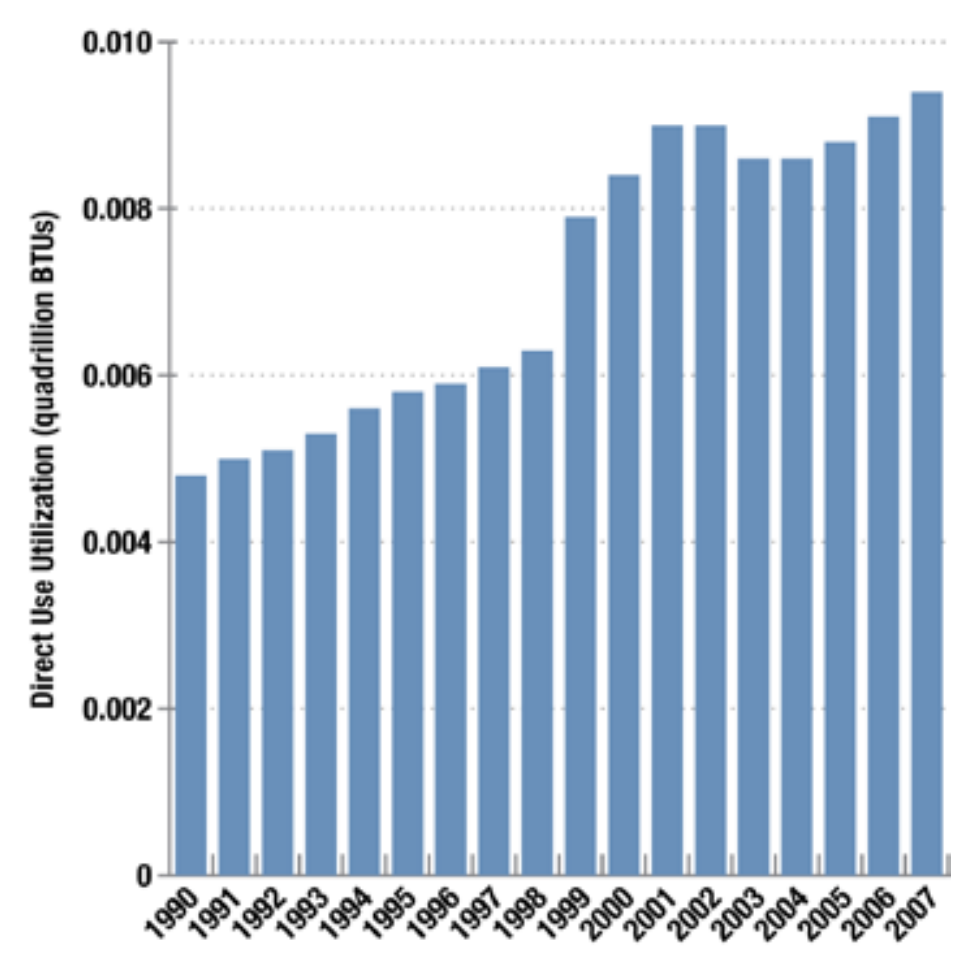

Source: Lund, J., Oregon Institute of Technology, Geo-Heat Center, March 2008.

\begin{tabular}{|c|c|}
\hline Year & $\begin{array}{c}\text { Direct Use Utilization } \\
\text { (Quadrillion BtU }\end{array}$ \\
\hline 1990 & 0.0048 \\
\hline 1991 & 0.0050 \\
\hline 1992 & 0.0051 \\
\hline 1993 & 0.0053 \\
\hline 1994 & 0.0056 \\
\hline 1995 & 0.0058 \\
\hline 1996 & 0.0059 \\
\hline 1997 & 0.0061 \\
\hline 1998 & $0 / 0063$ \\
\hline 1999 & 0.0079 \\
\hline 2000 & 0.0084 \\
\hline 2001 & 0.0090 \\
\hline 2002 & 0.0090 \\
\hline 2003 & 0.0086 \\
\hline 2004 & 0.0086 \\
\hline 2005 & 0.0088 \\
\hline 2006 & 0.0091 \\
\hline 2007 & 0.0094 \\
\hline
\end{tabular}

\footnotetext{
* In February 2009 the EIA released its annual, Geothermal Heat Pump Manufacturing Activities. The data within the report were only applicable for the 2007. 2008 data were estimated given annual escalation factors used by John Lund, OIT Geo-Heat Center.

† The annual escalation factor of $4 \%=$ average percent increase since 1990.
} 


\section{The U.S. GHP Installed Base is World's Largest - More than 1 Million Units*}

Installed GHP capacity in the United States in 2007 was equivalent to $10,839 \mathrm{MWt}$ with a capacity factor of 10 percent. The thermal energy consumed totaled 33,445 TJ/yr $(9,287$ GWh/yr), roughly 0.0317 quads (see Figure 24). In 2008, the geothermal heat pump capacity was estimated to be 12,031 MWt with an annual consumption of 37,124 TJ/yr (10,309 GWh/ yr). This estimate was produced using Lund's annual escalation factor for geothermal heat pumps, which was 11 percent for $2008 .{ }^{44}$

Figure 24. GHP Primary Energy Consumption

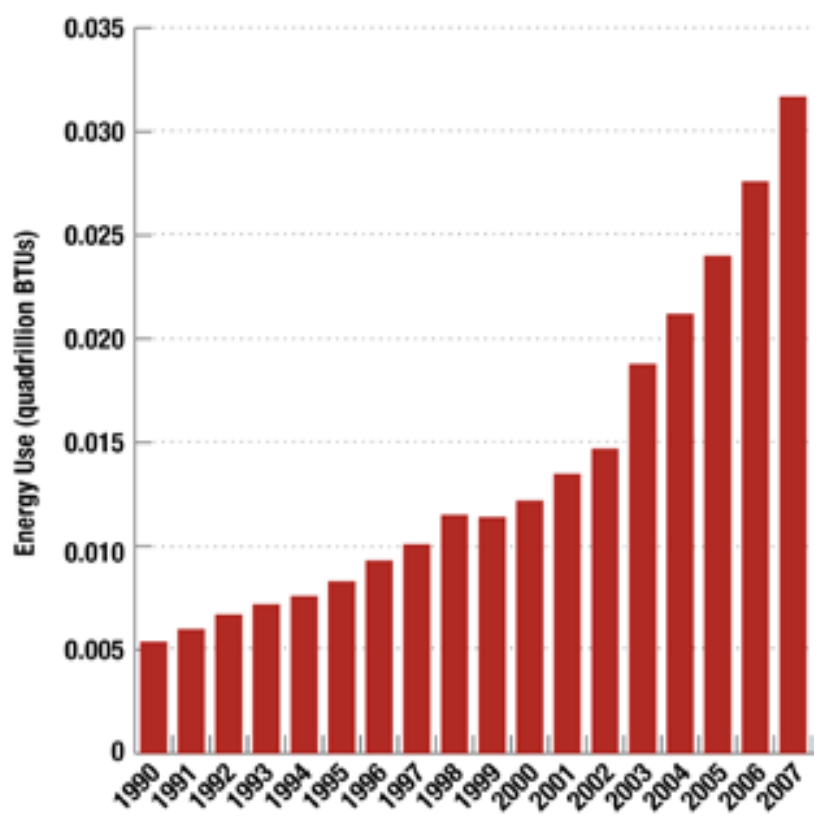

Source: EIA, "Geothermal Heat Pump Manufacturing Activities 2007" (Released February 2009)

Based on the latest Energy Information Administration (EIA) Form EIA-902, "Annual Geothermal Heat Pump Manufacturers Survey", GHP manufacturers shipped 86,396 GHPs in 2007, a $36 \%$ increase over the 2006 total of 63,682 . The total rated capacity of GHPs shipped in 2007 was 291,300 tons, which represents almost a 19\% increase over the 245,603 tons shipped in 2006 (see Figure 25). AHRI reported 2008 shipments of more than 71,000 units, indicating continued strong demand despite worsening economic conditions (see Table 7).

Table 7. Geothermal Heat Pump Shipments (1999-2008)

\begin{tabular}{|c|c|c|c|c|c|c|c|c|c|}
\hline 1999 & 2000 & 2001 & 2002 & 2003 & 2004 & 2005 & 2006 & 2007 & $2008^{\wedge}$ \\
\hline 41,679 & 35,581 & N/A & 37,139 & 36,439 & 43,806 & 47,830 & 63,682 & 86,396 & 71,000 \\
\hline
\end{tabular}

Source: EIA, AHRI, 2009

WaterFurnace, the Canadian GHP company and a market leader in the United States and Canada, witnessed a doubling of sales between 2003 and 2007, with a 26\% year-over-year sales increase from 2007 through 3Q 2008..$^{45}$

\footnotetext{
* In 2007, it was estimated that the number of heat pumps installed totaled over 800,000 . One geothermal heat pump has an assumed average size of $12 \mathrm{~kW}$. Therefore, the assumed 12,031 MWt installed for 2008 allows for an estimate of 1,002,583 heat pumps installed.

$\wedge$ Advance data from the AHRI.
} 
Figure 25. Capacity of GHP Shipments by Model Type (2009)*

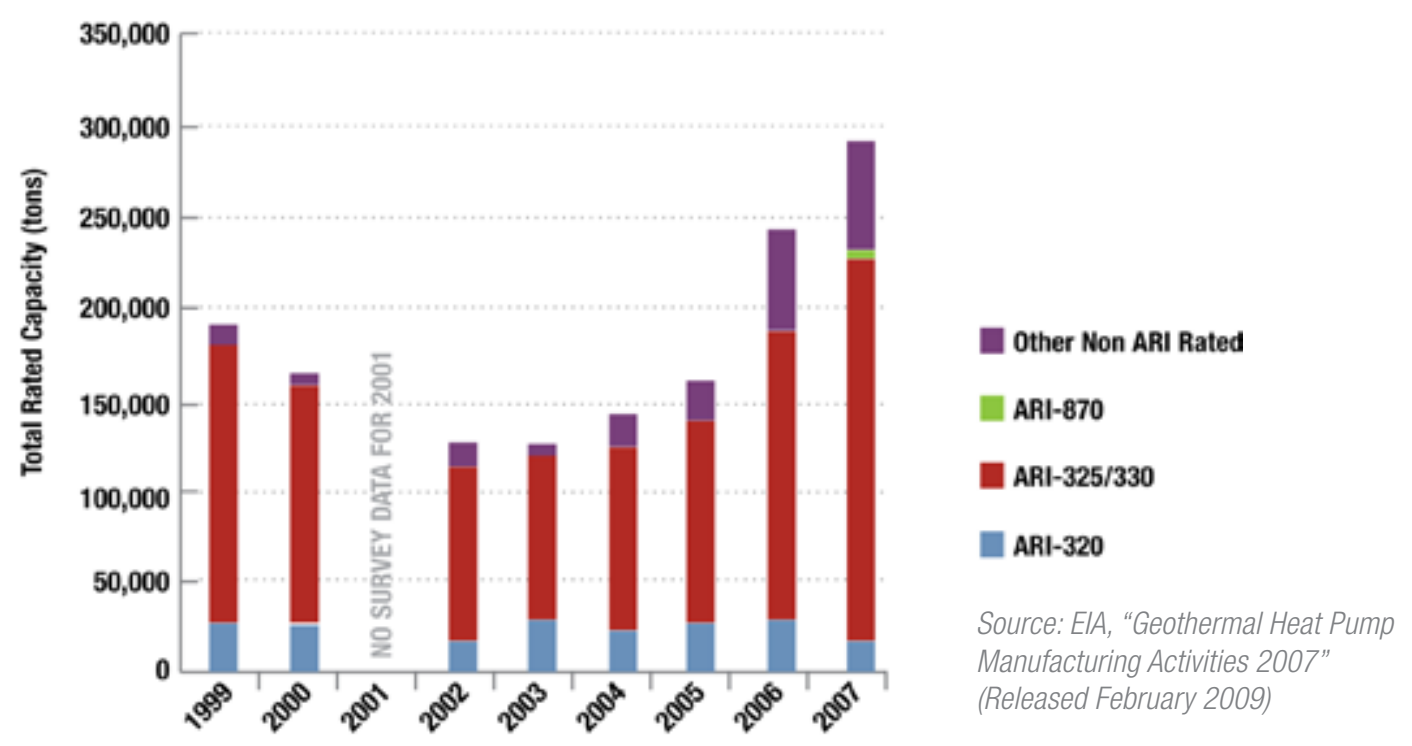

\section{U.S. GHP Market Segmentation - Evenly Divided Between Residential and Commercial Applications}

GHPs can be used in a wide variety of applications, including residential, commercial, institutional and multifamily buildings. Currently, GHP shipments are fairly evenly divided between residential and commercial building applications (see Figure 26). According to ClimateMater, GHPs were installed in 1 out of every 38 new U.S. homes in 2008. This represents a $2.6 \%$ market share for the segment. ${ }^{46}$ The retrofit market for schools has grown substantially in recent years; there are currently more than 600 schools with GHP systems.

As shown in Figure 27, GHPs have a presence in all census regions, although the market has historically been dominated by the Midwestern and southern states, which are home to the major GHP manufacturers and have more personnel trained in GHP installation and maintenance than other regions.

Figure 26. Geothermal heat pump domestic shipments by sector, 2007

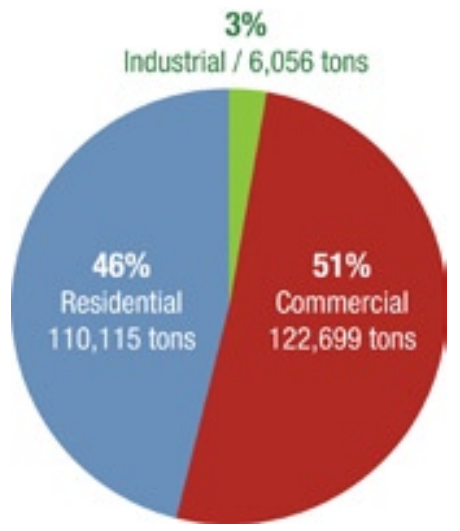

Source: EIA, "Geothermal Heat Pump Manufacturing Activities 2007” (Released February 2009)
Figure 27. GSHP Shipments by Census

Region in Tons (2007)

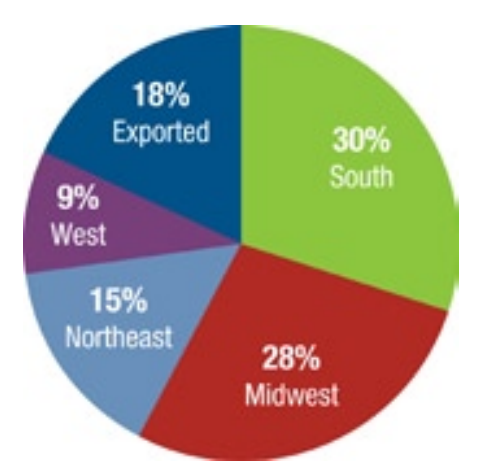

Source: EIA, "Geothermal Heat Pump Manufacturing Activities 2007" (Released February 2009)

\footnotetext{
* ARI 320 refers to ARI rated water source heat pumps, ARI 325 to ARI rated ground water source heat pumps (open loop), and ARI 330 to ARI ground source heat pumps (closed loop).
} 


\section{Four Companies Hold 80 Percent of the U.S. GHP Market}

Although 40 firms respond to the EIA's GHP survey,"47 just four companies account for over $80 \%$ of annual sales. ${ }^{48}$ The top four manufacturers are ClimateMaster (a unit of LSB Industries), Florida Heat Pump (a unit of Bosch), WaterFurnace International, Inc., and Trane (a business unit of Ingersoll Rand.) An additional 10-15 firms account for the remainder of the U.S. market. Some serve the entire nation while others cater to specific market niches. In addition, certain GHPs are rebranded and resold under different names. Major firms within this group include McQuay International (a unit of Daikin), Mammoth and several regional manufacturers. Carrier markets water-source heat pump and GHP systems designed by other manufacturers under their own label. ${ }^{49}$

\section{Tax Credits and Incentives Set to Increase GHP Deployment}

The GHP market still faces significant barriers, however, including: high installation and capital costs; a pervasive lack of consumer awareness; and insufficient market delivery infrastructure. In order for heat pumps to reach their full market potential, these barriers must be addressed through effective market conditioning strategies. ${ }^{50}$

First and foremost, GHP systems are generally more expensive than conventional heating and cooling systems due to the costs associated with installation of the ground connection. The remaining components, the "balance of system," cost roughly the same as the equipment that comprise common air-source heat pumps. Average installed costs for 2008 are roughly $\$ 5,000-\$ 6,000 /$ ton $^{*}$ for the residential market and $\$ 6,000$ to $\$ 10,000 /$ ton for commercial applications ${ }^{51}$ Though GHPs have higher initial capital costs their operation and maintenance costs tend to be lower than some conventional alternatives.

To encourage continued adoption of GHPs in the residential market, EESA of 2008 renewed the EPAct 2005 tax credit for GHPs that had been allowed to lapse. The credit covers 30 percent of the GHP project cost, not to exceed \$2,000. The recent Recovery Act of 2009 greatly enhanced the scope of the tax credit by removing the $\$ 2,000$ cap (see Looking Ahead section).

There are a variety of additional incentives available from Federal and state governments and utilities to encourage greater adoption of GHPs among residential, institutional and commercial consumers. Thirty-four states currently offer GHP incentives, generally in the form of rebates, loan programs, tax exemptions (property, sales and use), renewable and green building requirements for public buildings, stricter building codes that require specified energy efficiency requirements, public benefits funds created through utility surcharges, and green building incentives, such as expedited permitting. ${ }^{52}$ Other possible incentive options include design assistance programs, innovative loop leasing and financing strategies, low interest loans, consumer rebates, GHP utility rate tariffs, contractor training programs, to nurture the delivery infrastructure, and public support by Federal and state agencies, including program marketing and funding for demonstration and showcase facilities. ${ }^{53}$

* One ton is equivalent to $12,000 \mathrm{BTU} / \mathrm{hr}$. 


\section{International Activities}

\section{Worldwide Geothermal Capacity Continues to Grow}

The United States remained the leader in installed geothermal capacity in 2008, followed in order by the Philippines, Indonesia, Mexico and Italy (see Table 8). While international figures are not yet known for 2008, New Energy Finance estimates 335 MWe of capacity has been added outside the United States (see Table 9). Some important international geothermal developers include; Geodynamics (Australia), Petratherm (Australia), Green Rock Energy (Australia), Chevron Geothermal \& Power (USA), and Enel Green Power (Italy).

Table 8. Installed geothermal capacity of the top ten countries in 2007

\begin{tabular}{|l|c|}
\hline Country & $\begin{array}{c}\text { Installed Capacity } \\
\text { (MWe) }\end{array}$ \\
\hline USA & 2,687 \\
\hline Philippines & 1,970 \\
\hline Indonesia & 992 \\
\hline Mexico & 953 \\
\hline Italy & 811 \\
\hline Japan & 535 \\
\hline New Zealand & 472 \\
\hline Iceland & 421 \\
\hline El Salvador & 204 \\
\hline Costa Rica & 163 \\
\hline
\end{tabular}

Table 9. Total 2008 MWe increases by country

\begin{tabular}{|l|c|}
\hline Country & $\begin{array}{c}2008 \text { Increases in } \\
\text { Capacity (MWe) }\end{array}$ \\
\hline France & 1.5 \\
\hline Germany & 6.9 \\
\hline Iceland & 90.0 \\
\hline Indonesia & 60.0 \\
\hline Kenya & 35.0 \\
\hline New Zealand & 121.6 \\
\hline Philippines & 20.0 \\
\hline TOTAL & 335.0 \\
\hline
\end{tabular}

Source: New Energy Finance, 2008

Source: Bertani, R. "World Geothermal Generation in 2007" (September 2007)

\section{International Direct-Use Geothermal is Widespread}

Direct-use geothermal is widely utilized abroad. Iceland and Turkey both employ a tremendous amount of geothermal energy to serve their heating and cooling requirements (see Table 10). Iceland satisfies $89 \%$ of its heating and cooling needs with geothermal, whereas Turkey has increased its installed base of district heating systems from $820 \mathrm{MWt}$ to 1,495 MWt, almost 50\% in just 5 years. Japan has over 2,000 hot spring resorts, 5,000 public bath houses, and 15,000 hotels with natural hot springs. Switzerland makes extensive use of its geothermal resources as well, with more than 30,000 GHPs, and uses drain water from tunnels to heat homes and melt roadway ice and snow. ${ }^{54}$

* This is a 2007 figure. Current U.S. installed capacity is 3,040 MWe as of March 2009 (GEA). 
Table 10. Top direct-use countries

\begin{tabular}{|l|c|c|l|}
\hline Country & GWh/yr & MWt & Main Applications \\
\hline China & 12,605 & 3,687 & Bathing \\
\hline Sweden & 12,000 & 4,200 & GHP \\
\hline USA & 8,678 & 7,817 & GHP \\
\hline Turkey & 6,900 & 1,495 & District Heating \\
\hline Iceland & 6,806 & 1,844 & District Heating \\
\hline Japan & 2,862 & 822 & Bathing \\
\hline Hungary & 2,206 & 694 & Spas/Greenhouse \\
\hline Italy & 2,098 & 607 & Spas/Space heating \\
\hline New Zealand & 1,969 & 30 & Industrial Uses \\
\hline
\end{tabular}

Source: Lund, John (2007). Characteristics, Development and Utilization of Geothermal Resources. Geo-Heat Center, Oregon Institute of Technology, GHC Bulletin, p.6.

International installed GHP capacity has experienced strong growth in recent years. Annual growth rates exceed $10 \%$ over the last 10 years. Most of this activity occurred in the North American and European markets. ${ }^{55}$ The European GHP market is expected to experience continued strong growth due to a variety of energy efficiency and climate protection goals and policies by the European Union (EU) countries and stakeholder organizations. ${ }^{56}$ These include the EU Proposal for a Directive of the European Parliament and of the Council on the Promotion of Renewable Energy ${ }^{57}$; the Ground Reach Initiative, a collaborative effort to utilize GHPs to meet Kyoto Treaty climate targets ${ }^{58}$; and the European Geothermal Energy Council's recent strategy document..$^{59}$

As noted earlier, direct-use applications are quite diverse and include everything from agricultural to resorts and spas. Table 11 below contains a complete breakdown of direct-use categories. ${ }^{*}$

Table 11. Direct use application breakdown by installed capacity and annual energy use

\begin{tabular}{|l|c|c|}
\hline Application & Installed Capacity & Energy Use \\
\hline Geothermal Heat Pumps & $56.5 \%$ & $33.2 \%$ \\
\hline Bathing/swimming/spas & $17.7 \%$ & $28.8 \%$ \\
\hline Space heating (with district heating) & $14.9 \%$ & $20.2 \%$ \\
\hline Greenhouse heating & $4.8 \%$ & $7.5 \%$ \\
\hline Aquaculture & $2.2 \%$ & $4.2 \%$ \\
\hline Industrial & $1.8 \%$ & $4.2 \%$ \\
\hline Agricultural drying & $0.6 \%$ & $0.8 \%$ \\
\hline Cooling and snow melting & $1.2 \%$ & $0.7 \%$ \\
\hline Other & $0.3 \%$ & $0.4 \%$ \\
\hline
\end{tabular}

Source: Lund, John (2007). Characteristics, Development and Utilization of Geothermal Resources. Geo-Heat Center, Oregon Institute of Technology, GHC Bulletin, p.6.

* Dr. John Lund includes GHPs with other direct use geothermal applications. 


\section{Employment and Economic Benefits of Geothermal Power}

\section{Geothermal Industry - More than 25,000 Employed Nationwide}

Several studies have examined the employment and economic benefits of geothermal energy development. Perhaps the most obvious positive byproduct is the creation of high-paying, long-term jobs. Calpine has reported that the construction of a typical $50 \mathrm{MW}$ geothermal plant involves 160 people and 33 months of labor. ${ }^{60}$ In 2008, the GEA estimates that the geothermal industry roughly accounted for 9,000 jobs in operating, construction and manufacturing and an additional 16,000 supporting positions.

These figures do not incorporate the manufacturing and installation jobs generated separately by the GHP industry. According to the EIA, direct employment in the geothermal heat pump manufacturer industry alone accounted for 1,219 person-years in 2007. ${ }^{61}$ GHPs are a labor-intensive technology to manufacture and install. Based on estimates generated by WaterFurnace, each GHP requires 24 hours of manufacturing labor and 32 hours of installation labor, and a permanent job is created for every 18 installations. ${ }^{62}$ GHPs require a wide range of experience, with up to 30 individuals involved with each installation.

\section{Gross Revenue from Geothermal Royalties Increased 14\% between FY 2006 and FY 2008}

In addition to job creation, tax revenues from geothermal development can have a substantial impact on local economic growth. EPAct of 2005 increased these benefits such that the Federal, state and county governments will now receive $25 \%, 50 \%$ and $25 \%$ of geothermal revenues, respectively, from Federal leases. According to a report by the GEA, in 2008 geothermal facilities produced $\$ 9.1$ million in tax revenue for 31 counties in six states-an increase of $\$ 4.3$ million from the 2007 amount These counties tend to be sparsely populated rural areas where the revenue increases have noticeable positive effects; the counties overwhelmingly used the revenues to support public services, and infrastructure. In 2007 and 2008, six states received a total of $\$ 27$ million in geothermal tax revenues ${ }^{63}$, while the Federal government received \$13.5 million. 


\section{Looking Ahead - 2009 and Beyond}

\section{Conclusion}

In 2008, the United States geothermal energy industry experienced a rebirth. New research showing a dramatic increase in potential of geothermal as a major energy source, along with a volatile energy environment and climate change concerns, sparked renewed investment from government and industry. Projects currently underway may result in new breakthroughs in technology and cost efficiency for the industry, and it is poised for additional growth in 2009 despite challenging economic conditions.

At the time of publication, U.S. energy policy is rapidly evolving with significant new incentives for renewable energy development. The Recovery Act, signed by President Barack Obama on February 13, 2009, includes over $\$ 42$ billion for energy programs and more than $\$ 21$ billion in energy tax incentives, primarily for energy efficiency and renewable energy. The GTP received $\$ 400$ million, a substantial portion of DOE's Recovery Act funds devoted to efficient and renewable energy technologies. GTP will now have more capacity to implement the major provisions of the 2007 Energy Independence and Security Act. The GTP will distribute the Recovery Act funding to partners in industry and academia through competitive awards broadly focused on EGS development, geothermal component R\&D, low-temperature geothermal resources, innovative exploration techniques and geothermal heat pumps. Industry cost share will further increase investment, multiplying benefits to technology development.

The Recovery Act also includes enhanced tax provisions that provide assistance to geothermal power developers. The law extends the Renewable Energy PTCs for geothermal facilities put in place before January 1, 2013, which had been allowed to lapse, slowing industry investment. It also provides the opportunity for geothermal developers to take advantage of the ITC in lieu of the PTC when desirable, and allows the Department of the Treasury to offer grants in lieu of the tax credits. These revisions provide additional flexibility for geothermal developers. The grants are likely to be a more effective means of financing renewable energy projects since current economic conditions have largely eliminated tax equity financing as an option for developers.

GHPs also are likely to receive a big boost from the Recovery Act, which not only extended residential and commercial tax credits, but also removed a $\$ 2,000$ cap that existed under EESA. Residential customers may claim a tax credit up to $30 \%$ of the installed cost of their GHP systems, and commercial customers may receive up to 10\%. Other elements, such as accelerated depreciation, were also extended. Substantial funds from the Recovery Act have also been allocated to other offices within DOE, other Federal agencies, and channeled to state and local 
governments to improve building energy efficiency, and stimulate green jobs creation and economic growth. This new funding may also directly benefit GHPs and geothermal energy development. Some of the more notable Recovery Act funding provisions include:

- More than \$11 billion is provided in grants for state and local governments through the Department of Energy's Weatherization Assistance Program, which provides energy efficiency services to low-income households; the State Energy Program, which provides states with discretionary funding for energy efficiency and renewable energy projects and programs; and the new Energy Efficiency and Conservation Block Grant Program, which seeks to limit energy use and greenhouse gas emissions. Several jurisdictions have already devoted funding through these grant programs to a variety of renewable and efficient technologies, including geothermal heat pumps.

- Approximately $\$ 8.8$ billion was allocated to the Department of Education, to renovate schools and university campuses according to green standards.

- The Recovery Act sets aside \$3.7 billion for energy efficiency within the Department of Defense's substantial building stock. The Department has previously been an active supporter of geothermal heat pump technology use across its facilities.

- The Departments of the Interior and Veterans Affairs both received \$1 billion in multi-purpose funds that can be dedicated to renewable energy and energy efficiency projects and upgrades to their facilities. ${ }^{64}$

As of May 29, 2009, major legislation is currently moving through the U.S. Congress that has the potential to significantly change the way energy is produced and consumed in the United States. The American Clean Energy and Security Act of 2009 (H.R. 2454) seeks to gradually reduce carbon emissions (by 17\% below 2005 levels by 2020) and increase the proportion of energy that comes from renewable sources in the United States ( $20 \%$ by 2020$)$. While specific targets will likely change as the bill undergoes revisions in various congressional committees in the coming months, if enacted, it will undoubtedly lead to increased investment and deployment of renewable energy technologies in the United States. 


\section{End Notes}

1 Shepherd, William, "Energy Studies." London: Imperial College Press, (2003), p. 206.

2 Martin, Keith, “Geothermal Deal Structures”, Chadbourne \& Parke, LLP, 2008 Geothermal Investment Conference, (November 2008).

3 U.S. DOE Geothermal Technologies Program, Press Release, (2008).

4 Lund, John, Oregon Institute of Technology, Geo-Heat Center, (2007).

5 Geothermal Technologies Program, U.S. Department of Energy: "DOE Funds 21 Research, Development and Demonstration Projects for up to $\$ 78$ million to Promote Enhanced Geothermal Systems." http://www1.eere.energy.gov/geothermal/news_detail.html?news_id12018.

6 Google.org, http://www.google.org/egs/index.html

7 Geothermal Technologies Program, U.S. Department of Energy: "BLM Offers Geothermal Leases in Utah, Idaho and Oregon." http://www1.eere.energy.gov/geothermal/news_detail.html?news_id=12113

8 New Energy Finance, "Meltdown: How Iceland's Fall is Impacting Geothermal”, (November 2008).

9 New Energy Finance, "To Drill or Not to Drill: Geothermal and the Credit Crunch", (January 6, 2009).

10 Personal Communication with Karl Gawell, Executive Director, GEA

11 Electric Power Monthly, ElA, (March 2009).

12 International geothermal capacity figures for 2008 are not scheduled to be released until late 2009. Source: Bertani, R. "World Geothermal Generation in 2007", (September 2007)

13 United States Geological Survey, "Assessment of Moderate- and High-Temperature Geothermal Resources of the United States", (2008).

14 Geothermal Energy Association, "U.S. Geothermal Power Production and Development", (March 2009)

15 lbid.

16 Tester, J., et al., Massachusetts Institute of Technology, "The Future of Geothermal Energy: Impact of Enhanced Geothermal Systems (EGS) on the United States in the $21^{1 \text { st }}$ Century", (2006).

17 U.S. DOE Geothermal Technologies Program, (2008)

18 Ibid.

19 Ibid.

20 North American Clean Energy Magazine, "Assessment of the Price of Geothermal Power", Volume 3, Issue 1. (2009) (\$4,000/kW) Lovekin, J, et al., "Potential improvements to existing geothermal facilities in California", (2006) (\$3,000-\$3,500/kW) New Energy Finance, Direct Communication with Mark Taylor (\$3,600-\$3,900/kWh).

21 Sison-Lebrilla, Elaine and Valentino Tiangco, "Geothermal Strategic Value Analysis", California Energy Commission Report \#CEC-500-2005-105-SD, (June 2005), pgs.12-17.

22 Davidson, Paul "Declining energy prices extend to electricity”, USA TODAY, (December 17, 2008).

23 "To Drill or Not to Drill", New Energy Finance, (January 6, 2009), p.1.

24 “Geothermal Deal Structures", Presentation by Keith Martin, Chadbourne \& Parke, LLP, Geothermal Financing Summit 2008.

25 "What's Hot in Renewable Energy Project Financing" by Ed Feo, Milbank Tweed Hadley \& McCloy LLP, published in North American Clean Energy (www.nacleanenergy.com), Volume 2, Issue 1, (2008).

26 “Geothermal Deal Structures", Presentation by Keith Martin, Chadbourne \& Parke, LLP, Geothermal Financing Summit 2008.

27 Ibid.

28 "Geothermal Energy Stocks Should Recover Steam If Government Support Lasts", The Globe and Mail - Globe Investor Magazine, October 28, 2008.

29 "Geothermal Deal Structures", Presentation by Keith Martin, Chadbourne \& Parke, LLP, Geothermal Financing Summit 2008.

30 "To Drill or Not to Drill: Geothermal and the Credit Crunch", New Energy Finance, January 6, 2009, pgs. 1-2.

31 "Credit Crunch Darkens Solar's Prospects", Fortune, October 28, 2008. Via CNN.com.

32 "Geothermal Deal Structures", Presentation by Keith Martin, Chadbourne \& Parke, LLP, Geothermal Financing Summit 2008.

33 "Geothermal Energy - An Overnight Success in 104 Years", Dundee Capital Markets, Ian Tharp CFA, March 17, 2008, p. 27.

34 Jason Gold interview, January 9, 2009. 
35 New Energy Finance, "To Drill or Not to Drill: Geothermal and the Credit Crunch", January 6, 2009, p. 3.

36 Lazard Investment Bank, (2008). Download at: http://www.narucmeetings.org/Presentations/2008\%20EMP\%20Levelized\%20Cost\%20of\%20 Energy\%20-\%20Master\%20June\%202008\%20(2).pdf

37 Ibid.

38 Database of State Incentives for Renewable Energy (DSIRE). Available at: www.dsireusa.org

39 U.S DOE EERE Network News, 2008

40 Mostow, P. and Braff, A., "Geothermal Site Acquisition and Early Development: Key Legal Issues and Emerging Strategies", Presented at Geothermal Energy 2008.

41 U.S. Department of the Interior, Bureau of Land Management, "Record of Decision and Resource Management Plan Amendments for Geothermal Leasing in the Western United States", (December 2008).

42 Lund et al, "Direct application of geothermal energy: 2005 Worldwide review", Geothermics 34 (2005) 691-727

43 Characteristics, Development and Utilization of Geothermal Resources, John W. Lund, Geo-Heat Center, Oregon Institute of Technology, GHC Bulletin, June 2007, p.6.

44 Lund et al, "Direct application of geothermal energy: 2005 Worldwide review", Geothermics 34 (2005) 691-727

45 WaterFurnace Investors Presentation, (November, 2008). Available at www.waterfurnance.com.

46 Personal communication with ClimateMaster staff, (April 2009).

47 Holihan, Peter, "Analysis of Geothermal Heat Pump Manufacturers Survey Data", Energy Information Administration, Renewable Energy 1998: Issues and Trends, p.59

48 The American Council for an Energy-Efficient Economy, "Emerging Technologies Report: Residential Ground-Source Heat Pumps July”, (2007), p. 3.

49 Hughes, Patrick, "Geothermal (Ground-Source) Heat Pumps: Market Status, Barriers to Adoption, and Actions to Overcome Barriers, Oak Ridge National Laboratory, Report \# ORNL/TM-2008/232 (December 2008), p. 17.

50 lbid.

51 Personal communication with ClimateMaster staff, (April 2009).

52 Database of State Incentives for Renewable Energy (DSIRE). Available at: www.dsireusa.org.

53 Johnson, Katherine and Ed Thomas, "Helping Utilities and Customers Quantify the Benefits of Geothermal Heat Pumps", Market Development Group. Paper presented at IEA Heat Pump Conference, (2008).

54 Ibid.

55 Le Feuvre, P., Kummert, M., "Ground Source Heat Pumps in the UK - Market Status and Evaluation." Proceedings of the 9 $9^{\text {th }}$ Annual IEA Heat Pump Conference, (2008).

56 Council of the European Union, Presidency conclusions 7224/1/07 REV 1: III. An integrated climate and energy policy, (2007) p. 10-14. Download at: http://www.consilium.europa.eu/ueDocs/cms_Data/docs/pressData/en/ec/93135.pdf

57 "Proposal for a Directive of the European Parliament and of the Council on the Promotion of the Use of Energy from Renewable Sources", Brussels, (January 23, 2008) Download at: http://ec.europa.eu/energy/climate_actions/doc/2008_res_directive_en.pdf

58 www.groundreach.eu

59 "Research Agenda for Geothermal Energy - Strategy 2008 to 2030", European Geothermal Energy Council (EGEC), (2008). Download at: http://www.groundreach.eu/script/tool/forg/doc795/EGEC\%20RESEARCH\%20AGENDA\%202009.pdf

60 Ibid, p.3.

61 Form EIA-902, "Annual Geothermal Heat Pump Manufacturers Survey", Released February, 2009.

62 "WaterFurnace Renewable Energy Is Poised to Contribute to Economic Recovery and Long-Term Energy Goals", Reuters, (Feb 16, 2009). Article's figures based on an internal WaterFurnace study.

63 "Geothermal Revenue under the Energy Policy Act of 2005: Income Distribution at Federal, State and County Levels." GEA, (2008). pgs. 11-12.

64 Sissine, Fred et. al., Congressional Research Service, "Energy Provisions in the American Recovery and Reinvestment Act of 2009", (2009). 


\section{References}

American Council for an Energy-Efficient Economy (2007). Emerging Technologies Report - Residential Ground-Source Heat Pumps, p. 3.

Bertani, Ruggero (2007). World Geothermal Generation in 2007. pp. 8-19 GHC Bulletin September 2007.

Cambridge Energy Research Associates (2008).

Commission of the European Communities. 2008. Proposal for a Directive of the European parliament and of the council on the promotion of the use of energy from renewable sources. Brussels, 23.1.2008. Download at: http://ec.europa.eu/energy/climate_actions/doc/2008_res_directive_en.pdf

Council of the European Union. 2007: Presidency conclusions - Brussels, 8/9 March 2007 (7224/1/07 REV 1) Section III; An integrated climate and energy policy. p. 10-14. Download at www.consilium.europa.eu/ueDocs/cms_Data/docs/pressData/en/ec/93135.pdf

Davidson, Paul (2008). Declining energy prices extend to electricity. USA TODAY December 17, 2008.

Database of State Incentives for Renewable Energy (DSIRE) website: www.dsireusa.org

Energy Information Administration, U.S. Department of Energy (2009). Electric Power Monthly, March 2009.

www.eia.doe.gov/cneaf/electricity/epm/epm_sum.html

Energy Information Administration, U.S. Department of Energy (2009). Geothermal Heat Pump Manufacturing Activities 2007. www. eia. doe.gov/fuelrenewable.html

European Geothermal Energy Council (2008). Research Agenda for Geothermal Energy - Strategy 2008 to 2030. www.groundreach.eu/script/tool/forg/doc795/EGEC\%20RESEARCH\%20AGENDA\%202009.pdf

Feo, Ed of Milbank Tweed Hadley \& McCloy LLP (2008). What's Hot in Renewable Energy Project Financing. North American Clean Energy Vol. 2, Issue 1.

Fleischmann, Daniel J. (2007). Getting Geothermal Electricity Projects Online, Presentation by ORMAT Nevada, Inc., July 23, 2007.

Gawell, Karl, Geothermal Energy Association (GEA) (2009). Personal Communication.

Geothermal Energy Association (2005). Geothermal Industry Employment: Survey Results and Analysis. p. 2.

Geothermal Energy Association, U.S. Geothermal Power Production and Development (March 2009)

www.geo-energy.org/publications/reports/Industry_Update_March_Final.pdf

Geothermal Energy Association (2008). Geothermal Revenue Under the Energy Policy Act of 2005: Income Distribution at Federal, State and County Levels. p. 11-12.

Geothermal Resource Council (2009). Assessment of the Price of Geothermal Power. North American Clean Energy Magazine, Vol. 3 Issue 1.

Geothermal Technologies, U.S. Department of Energy website: www1.eere.energy.gov/geothermal/

Geothermal Technologies Program, U.S. Department of Energy. BLM Offers Geothermal Leases in Utah, Idaho and Oregon. www1.eere.energy.gov/geothermal/news_detail.html?news_id=12113

Geothermal Technologies Program, U.S. Department of Energy DOE Funds 21 Research, Development and Demonstration Projects for up to $\$ 78$ million to Promote Enhanced Geothermal Systems. www1.eere.energy.gov/geothermal/news_detail.html?news_id12018

Google.org website: www.google.org/egs/index.html

Ground Reach website: www.groundreach.eu

Hughes, Patrick (2008). Geothermal (Ground-Source) Heat Pumps: Market Status, Barriers to Adoption, and Actions to Overcome Barriers. Oak Ridge National Laboratory (ORNL/TM-0000/00).

International Partnership for Geothermal Technologies website: http://internationalgeothermal.org

Jason Gold interview, January 9, 2009.

Johnson, Katherine and Thomas, Ed. (2008). Helping Utilities and Customers Quantify the Benefits of Geothermal Heat Pumps. Market Development Group. Paper presented at IEA Heat Pump Conference, 2008.

Khan, Ali (2008). The Geysers Geothermal Field, an Injection Success Story. Geothermal Technologies Program - 2008 
Lazard, (2008).

www. narucmeetings.org/Presentations/2008\%20EMP\%20Levelized\%20Cost\%20of\%20Energy\%20-\%20Master\%20June\%202008\%20(2).pdf

Le Feuvre, P., Kummert, M., (2008). Ground Source Heat Pumps in the UK - Market Status and Evaluation. In: Proc. $9^{\text {th }}$ Annual IEA Heat Pump Conference 2008.

Lovekin, James, et al. (2006). Potential improvements to existing geothermal facilities in California. GRC Transactions, Vol. 30 pp. 885-890

Lund, John (2007). Characteristics, Development and Utilization of Geothermal Resources. Geo-Heat Center, Oregon Institute of Technology, GHC Bulletin, p.6.

Lund, John, et al. (2005). Direct application of geothermal energy: 2005 Worldwide review. Geothermics 34 pp.691-727

Martin, Keith (2008). Geothermal Deal Structures. Chadbourne \& Parke, LLP. November 2008 Geothermal Investment Conference.

Mostow, P. and Braff, A (2008). Geothermal Site Acquisition and Early Development: Key Legal Issues and Emerging Strategies. Presented at Geothermal Energy 2008

New Energy Finance (2008). Meltdown: How Iceland's fall is impacting geothermal.

New Energy Finance (2009). Direct communication with Mark Taylor.

New Energy Finance (2009). To Drill or Not to Drill: Geothermal and the Credit Crunch.

Raser Technologies website: www.rasertech.com/geothermal/projects-in-development

Shepherd, William (2006). Energy Studies.London. pp. 206; Imperial College Press, 2003

Silcoff, Sean (2008). Geothermal Energy Stocks Should Recover Steam If Government Support Lasts. The Globe and Mail, October 28, 2008.

Sissine, Fred, et al. (2009). Energy Provisions in the American Recovery and Reinvestment Act of 2009. Prepared by the Congressional Research Service.

Tester, J., et al. (2006). The Future of Geothermal Energy: Impact of Enhanced Geothermal Systems (EGS) on the United States in the $21^{\text {st }}$ Century.

Tharp, lan and Mahesh, Sumeet (2008). Geothermal Energy - An Overnight Success in 104 Years. Dundee Capital Markets March 17, 2008 , p. 27.

US Renewables Group (2007). Geothermal Investment: An Equity Provider's Perspective, Geothermal Investors' Forum, October 2007.

United States Geological Survey, U.S. Department of the Interior (2008). Assessment of Moderate- and High-Temperature Geothermal Resources of the United States

WaterFurnace Investors Presentation, November, 2008, www. waterfurnance.com

Woody, Todd (2008). Credit Crunch Darkens Solar’s Prospects. Fortune, October 24, 2008. Via CNN.com 
(This page intentionally left blank) 


\section{Geothermal Web Sites}

\section{Geothermal Energy Association (GEA)}

www.geo-energy.org/

\section{Geothermal Resource Council (GRC)}

www.geothermal.org/

International Energy Agency Geothermal Implementing Agreement (IEA - GIA)

www.iea-gia.org/

\section{Geothermal Heat Pump Consortium}

www.geoexchange.org/

\section{International Ground Source Heat Pump Association}

www.igshpa.okstate.edu/

\section{Geo-Heat Center, Oregon Institute of Technology}

geoheat.oit.edu/

\section{Lawrence Berkeley National Laboratory Geothermal Program}

esd.Ibl.gov/ER/geolbnl.html

\section{National Renewable Energy Laboratory (NREL) Geothermal Technologies}

nrel.gov/geothermal/

\section{Oak Ridge National Laboratory}

www.ornl.gov

\section{Sandia National Laboratories Geothermal Research Department}

www.sandia.gov/geothermal/

\section{U.S. Geological Survey (USGS)}

www.usgs.gov/

\section{U.S. Bureau of Land Management (BLM) Geothermal Program}

www.blm.gov/wo/st/en/prog/energy/geothermal.html

\section{U.S. Department of Energy Geothermal Technologies Program}

www.eere.energy.gov/geothermal/

\section{Key Report Contacts}

For more information on this report, please contact:

Ed Wall, Program Manager, Geothermal Technologies Program, U.S. Department of Energy 202-586-0410; ed.wall@ee.doe.gov

\section{On the Cover}

Electricity generated from U.S. geothermal sources, such as the Desert Peak geothermal field in Nevada, reached 15 billion kilowatt-hours in 2008. Courtesy of Ormat Technologies Inc.

U.S. DEPARTMENT OF

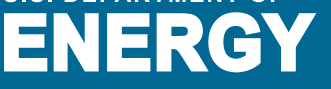

Energy Efficiency \& Renewable Energy
Prepared by the National Renewable Energy Laboratory (NREL) NREL is a national laboratory of the U.S. Department of Energy Office of Energy Efficiency and Renewable Energy Operated by the Alliance for Sustainable Energy, LLC
For more information contact: EERE Information Center 1-877-EERE-INF (1-877-337-3463) www.eere.energy.gov/informationcenter

Printed with a renewable-source ink on paper containing at least $50 \%$ wastepaper, including $10 \%$ post consumer waste. 